\title{
Biogasoline production by co-cracking of model compound mixture of bio-oil and ethanol over HSZM-5
}

\author{
Shurong Wang*, Qinjie Cai, Xiangyu Wang, Li Zhang, Yurong Wang, Zhongyang Luo \\ State Key Laboratory of Clean Energy Utilization, Zhejiang University, Hangzhou 310027, Zhejiang, China
}

\section{A R T I C L E I N F O}

Article history:

Received 5 December 2013

Accepted 22 January 2014

Published 20 May 2014

\section{Keywords:}

Bio-oil

Molecular distillation

Mixed-model compound mixtures

Co-cracking

Bio-gasoline

\begin{abstract}
A B S T R A C T
Acids and ketones in biomass pyrolysis oil (bio-oil) can be readily cracked to produce hydrocarbons. They can also be enriched in the distilled fraction using molecular distillation techniques. To simulate the actual composition of the distilled fraction, the co-cracking performance of mixtures of hydroxypropanone, cyclopentanone, and acetic acid with ethanol in a fixed-bed reactor over an HZSM- 5 catalyst was studied. The influences of reaction temperature and pressure on the reactant conversion, selectivity, and composition of the oil phase were investigated. At a low reaction temperature of $340{ }^{\circ} \mathrm{C}$, the conversions of acetic acid and ethanol were as low as $67.9 \%$ and $74.4 \%$, respectively, and the oil phase had a low hydrocarbon content of 59.8\%, with large amounts of oxygenated byproducts. Cracking under atmospheric pressure also generated a low-quality oil phase with a very low selectivity of only $10.8 \%$. Increasing the reaction temperature promoted reactant conversion and improved the deoxygenation efficiency, whereas increasing the reaction pressure significantly promoted hydrocarbon production. The optimum conditions for biogasoline production were $400{ }^{\circ} \mathrm{C}$ and $2 \mathrm{MPa}$. Under these conditions, the reactant conversion reached $100 \%$ and the oil phase selectivity was $31.5 \mathrm{wt} \%$. This oil phase consisted entirely of hydrocarbons, 91.5 $\mathrm{wt} \%$ of which were aromatic hydrocarbons, indicating that the HZSM- 5 catalyst had high activity for deoxygenation and aromatization reactions during cracking. In addition, characterization of the spent catalysts and stability tests showed that the catalyst was deactivated after a long reaction time. However, the catalytic activity was recovered by catalyst regeneration.
\end{abstract}

(C) 2014, Dalian Institute of Chemical Physics, Chinese Academy of Sciences. Published by Elsevier B.V. All rights reserved.

\section{Introduction}

With the growing fossil fuel crisis and increasingly severe environmental pollution, the use of renewable and clean biomass is receiving global attention [1-3]. Among methods of using biomass, fast pyrolysis has great potential, Because it can efficiently convert solid biomass to liquid bio-oil [4-6]. However, the inferior properties of bio-oil, such as high oxygen content, high water content, and instability, limit its use as a fuel for vehicles [7]. It is therefore necessary to upgrade bio-oil for such high-grade uses.

At present, the main bio-oil upgrading techniques are catalytic cracking, catalytic hydrogenation, catalytic esterification, catalytic steam reforming, and emulsification [8]. Catalytic cracking, using a zeolite catalyst, is a promising bio-oil upgrading technique, which can remove oxygen from the bio-oil in the form of $\mathrm{H}_{2} \mathrm{O}, \mathrm{CO}$, and $\mathrm{CO}_{2}$ and convert the bio-oil to high-grade hydrocarbon fuels [9-12].

\footnotetext{
* Corresponding author. Tel: +86-571-87952801; +86-571-87951616; E-mail: srwang@zju.edu.cn This work was supported by the National Natural Science Foundation of China (51276166), the National Basic Research Program of China (973 Program, 2013CB228101), the National Science and Technology Supporting Plan Through Contract (2011BAD22B06), Zhejiang Provincial Natural Science Foundation of China (R1110089), and the Program for New Century Excellent Talents in University (NCET-10-0741). 
The composition of bio-oil is very complicated. It has a high content of oxygenated components such as carboxylic acids, ketones, alcohols, aldehydes, phenols, ethers, esters, and sugars $[13,14]$. Although direct cracking of crude bio-oil produces some liquid hydrocarbon fuel, serious catalyst deactivation by coking occurs [15]. To investigate the detailed cracking mechanism of each component in bio-oil, the cracking behavior of different model compounds in bio-oil has been studied. It was found that some small-molecule compounds such as alcohols, acids, and ketones have high reactivities, whereas phenols have low reactivities $[16,17]$. In addition, macromolecules such as sugars and phenols in bio-oil easily form coke deposits on catalysts [18].

To improve the efficiency of bio-oil cracking, it is therefore necessary to enrich components with high cracking activities. Thermosensitive bio-oil can be efficiently separated into the corresponding distilled fraction and a residual fraction using the molecular distillation technique. In our previous studies on the molecular distillation of bio-oil, it was found that the distilled fraction had a high content of small-molecule ketones and acids such as hydroxypropanone (HPO), cyclopentanone (CPO), and acetic acid (HOAc), whereas macromolecules such as sugars and phenols were enriched in the residual fraction [19-21]. The cracking properties of the distilled fraction of bio-oil were therefore better than those of crude bio-oil.

Although the cracking properties of the distilled bio-oil fraction are better than those of crude bio-oil, direct cracking may still cause coking problems because of the high oxygen content and high degree of unsaturation. To evaluate the influence of oxygen content and degree of unsaturation of bio-oil on the cracking performance, some researchers have introduced the concept of the effective hydrogen to carbon ratio, $(\mathrm{H} / \mathrm{C})_{\mathrm{eff}}$ $[14,22]$, as expressed in equation $(\mathrm{H} / \mathrm{C})_{\mathrm{eff}}=(\mathrm{H}-2 \mathrm{O}-3 \mathrm{~N}-$ 2S)/C. Mentzel et al. [14] found that catalyst deactivation occurred more easily in the cracking of low $(\mathrm{H} / \mathrm{C})_{\text {eff }}$ compounds.

According to the equation, the $(\mathrm{H} / \mathrm{C})$ eff values for HPO, CPO, and HOAc are only $0.67,1.2$, and 0 , respectively, suggesting that the catalyst is easily deactivated during cracking of these compounds. The addition of compounds with relatively high $(\mathrm{H} / \mathrm{C})_{\text {eff }}$ values as coreactants to increase the overall $(\mathrm{H} / \mathrm{C})_{\text {eff }}$ may therefore be an efficient way to improve the stability of the cracking process. Aliphatic alcohols are ideal cracking coreactants because they have a relatively high $(\mathrm{H} / \mathrm{C})_{\text {eff }}$ value of 2 . In the study of co-cracking of methanol and bio-oil model compounds by Mentzel et al. [14], it was found that the catalyst lifetime was significantly increased and the conversion capacity increased tenfold. Valle et al. [18] used thermally treated bio-oil and then methanol for co-cracking, and the reaction stability was improved. Our previous study of the co-cracking of ketones (HPO or CPO) with alcohols also showed that the addition of alcohols enhanced the deoxygenation of ketones and the production of hydrocarbons [23,24]. In this work, mixtures of HPO, $\mathrm{CPO}$, and HOAc were selected as model compounds to study the co-cracking behavior with ethanol (EtOH). The influences of reaction temperature and pressure on reactant conversion, selectivity, and composition of the oil phase were investigated to determine the most suitable reaction conditions.

\section{Experimental}

HPO was purchased from Alfa Aesar (Ward Hill, MA, USA), CPO was purchased from Aladdin Industrial Corporation (Shanghai, China), and HOAc and EtOH were purchased from the Sinopharm Chemical Reagent Co. (Beijing, China). In our previous studies, it was found that $70 \mathrm{wt} \%$ alcohols mixed with ketones efficiently generated oil phase products [23]. Therefore, mixtures containing $70 \mathrm{wt} \% \mathrm{EtOH}$ and $30 \mathrm{wt} \%$ model compound mixture were again used in this work. Based on the HPO, CPO, and HOAc contents of crude bio-oil and their separation characteristics during molecular distillation [19-21], the weight ratio of HPO, CPO, and HOAc in the model compound mixture was set at 6:1:5, i.e., $15 \mathrm{wt} \% \mathrm{HPO}, 2.5 \mathrm{wt} \% \mathrm{CPO}$, and $12.5 \mathrm{wt} \%$ HOAc. The HZSM-5 ( $\mathrm{Si} / \mathrm{Al}=25)$ zeolite catalyst used in the experiments was activated at $550{ }^{\circ} \mathrm{C}$ for $6 \mathrm{~h}$ and then sieved to 40-60 mesh.

Catalytic cracking experiments were performed in a fixed-bed reactor. The catalyst (about $2 \mathrm{~g}$ ) was supported on quartz wool in the reactor, which was a stainless-tube with an inner diameter of $8 \mathrm{~mm}$. The mixed reactants were pumped using an HPLC pump and entered the reactor after vaporization with $\mathrm{N}_{2}$. The reaction pressure was regulated using $\mathrm{N}_{2}$ at a flow rate of $30 \mathrm{~mL} / \mathrm{min}$. The weight hourly space velocity of the reactants was kept at $3 \mathrm{~h}^{-1}$. The outlet gases from the reactor were cooled by a condenser to separate them into liquid products and non-condensable gases. Each experimental run lasted $3 \mathrm{~h}$, and the reaction temperature and pressure were set within the ranges $340-430{ }^{\circ} \mathrm{C}$ and $0.1-3 \mathrm{MPa}$.

The gaseous products were quantified using an online gas chromatograph (Agilent 7890A, Agilent Technologies, Palo Alto, CA, USA). The liquid products had an obviously separable oil phase and an aqueous phase. The oil phase was analyzed using a gas chromatography-mass spectrometry system and quantified using the area normalization method. Finally, the residual reactants in the liquid products were quantified by gas chromatography using the external reference method to calculate the conversion of the reactants based on the feed mass. The selectivities of the liquid products were calculated based on the mass of oil phase and aqueous phase collected (excluding unconverted reactants) and the mass of converted reactants.

The Brunauer-Emmett-Teller (BET) specific surface areas of blank HZSM-5 and spent catalysts were measured by $\mathrm{N}_{2}$ adsorption-desorption at $-196{ }^{\circ} \mathrm{C}$, using an Autosorb-1 Quantachrome apparatus.

\section{Results and discussion}

\subsection{Effects of reaction temperature and pressure}

\subsubsection{Reactant conversion}

The effect of temperature on the conversion of the model compound mixture and EtOH at $2 \mathrm{MPa}$ is shown in Fig. 1(a). At $340{ }^{\circ} \mathrm{C}$, HPO and CPO were almost completely converted, but the conversions of HOAc and EtOH were low, $67.9 \%$ and $74.4 \%$, respectively. This might be a result of the low catalytic capacity of the catalyst at low temperature and the low activities of 

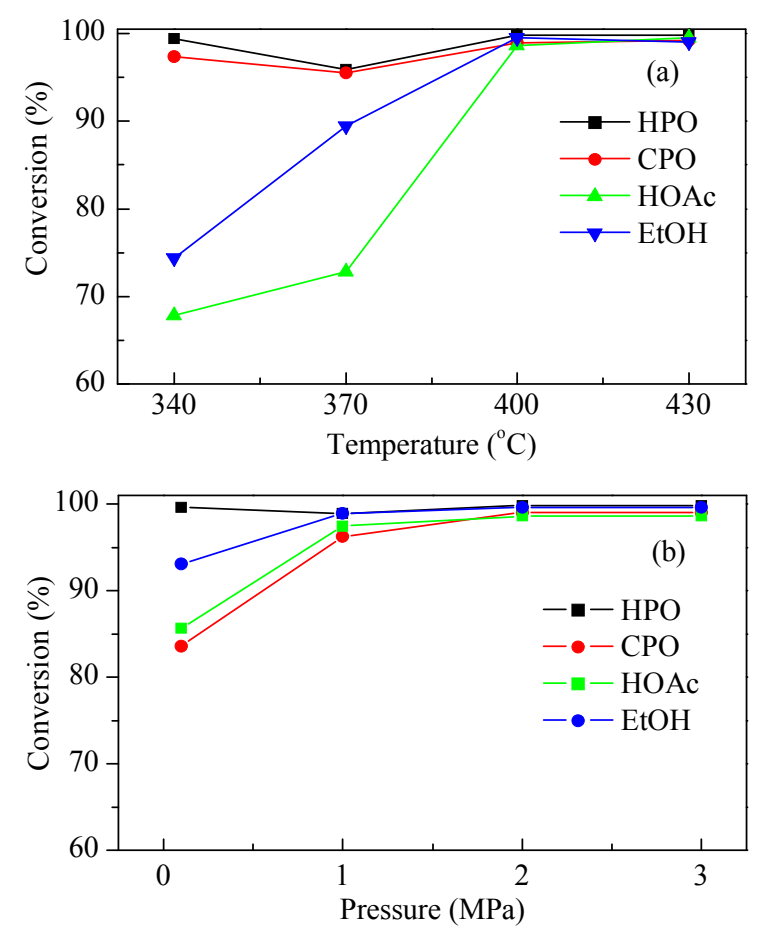

Fig. 1. Conversion of reactants using different conditions: (a) $2 \mathrm{MPa}$; (b) $400{ }^{\circ} \mathrm{C}$.

HOAc and EtOH molecules, whereas HPO and CPO showed higher activities. However, the converted HPO molecules mainly underwent intermolecular dehydration reactions to form ketones and other oxygenated byproducts at low reaction temperatures [23]. In a study of CPO conversion over acidic zeolites by Huang et al. [25], it was also found that CPO tended to form oxygenated polymers by condensation at low temperatures. Therefore, although the conversion of ketones is very high at low temperatures, the products may not be the desired hydrocarbons. The conversion of HOAc at low temperatures has been proved by Gayubo et al. [17] to be very difficult. They found that acetone, which is produced by ketonization of HOAc during cracking, was generated in large amounts when the temperature was above $400{ }^{\circ} \mathrm{C}$. As the temperature was reduced to $370{ }^{\circ} \mathrm{C}$, the conversion of EtOH clearly increased to $89.5 \%$, and the conversion of HOAc also increased to $72.8 \%$, but the conversions of HPO and CPO decreased slightly. The main reason for this phenomenon might be that increasing the reaction temperature leads to an increase in the molecular activities of HOAc and EtOH, but the catalytic capacity is not sufficiently high. Consequently, competition occurs among the reactants, leading to an increase in $\mathrm{HOAc}$ and $\mathrm{EtOH}$ conversions, but has little effect on the HPO and CPO conversions. At $400{ }^{\circ} \mathrm{C}$ or above, the catalytic capacity improved further, and not only were the high conversions of HPO and CPO maintained, but HOAc and EtOH were almost completely converted.

Figure 1(b) shows the conversion of the model compound mixture and EtOH at $400{ }^{\circ} \mathrm{C}$ at different reaction pressures. HPO, CPO, HOAc, and EtOH all showed conversions of $97 \%$ or more under these pressurized conditions and were almost completely converted when the pressure was increased to above $2 \mathrm{MPa}$. At atmospheric pressure, HPO was also almost completely converted, but the conversions of CPO, HOAc, and EtOH were low, 83.6\%, 85.6\%, and 93.1\%, respectively.

\subsubsection{Liquid-product selectivity}

The liquid product obtained by cracking consisted of two separable layers. The upper layer was an oil phase product, and the bottom layer was a clear aqueous-phase product, as shown in Fig. 2(a). In addition, the oil phases obtained under different conditions were different colors, as shown in Fig. 2(b), indicating that the compositions of the oil phases were distinct.

Figure 3(a) shows the liquid product selectivities at $2 \mathrm{MPa}$ and different temperatures. At $340{ }^{\circ} \mathrm{C}$, although the oil phase selectivity was $33.1 \%$, the oil phase was brown in appearance, suggesting that it contained many oxygenated byproducts. When the reaction temperature rose to $370{ }^{\circ} \mathrm{C}$, the color of the oil phase changed to fawn. So, although the oil phase selectivity decreased to $27.6 \%$, the actual selectivity for hydrocarbons might be higher. At $400{ }^{\circ} \mathrm{C}$ or above, the oil phase selectivity remained above $31 \%$, and the oil phase was light yellow. Based

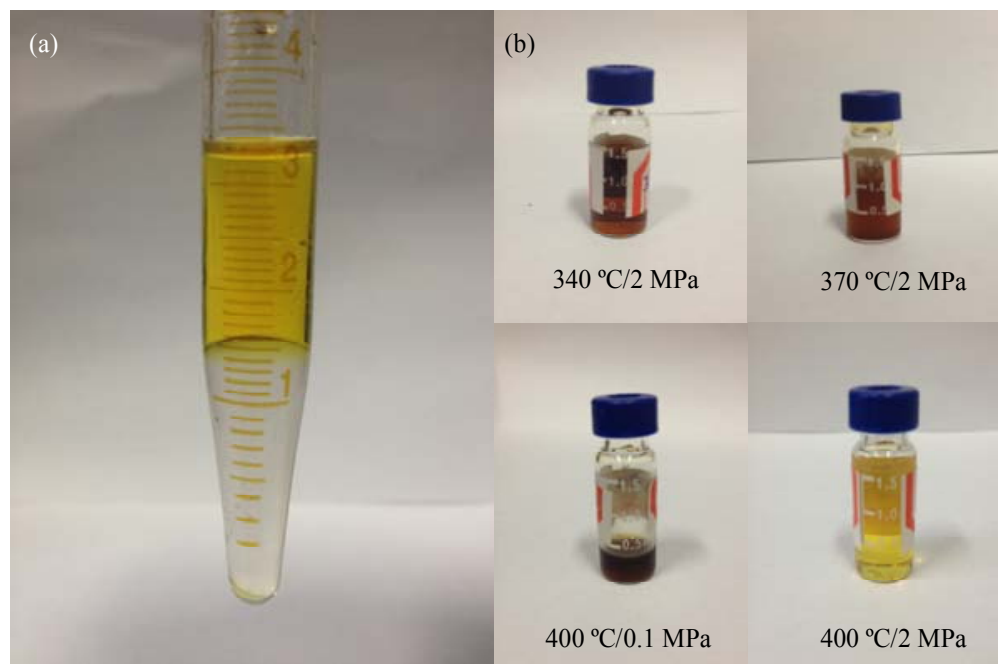

Fig. 2. (a) Photographs of liquid products showing two separable phases at $400^{\circ} \mathrm{C} / 2 \mathrm{MPa}$; (b) Oil phases obtained under different reaction conditions. 

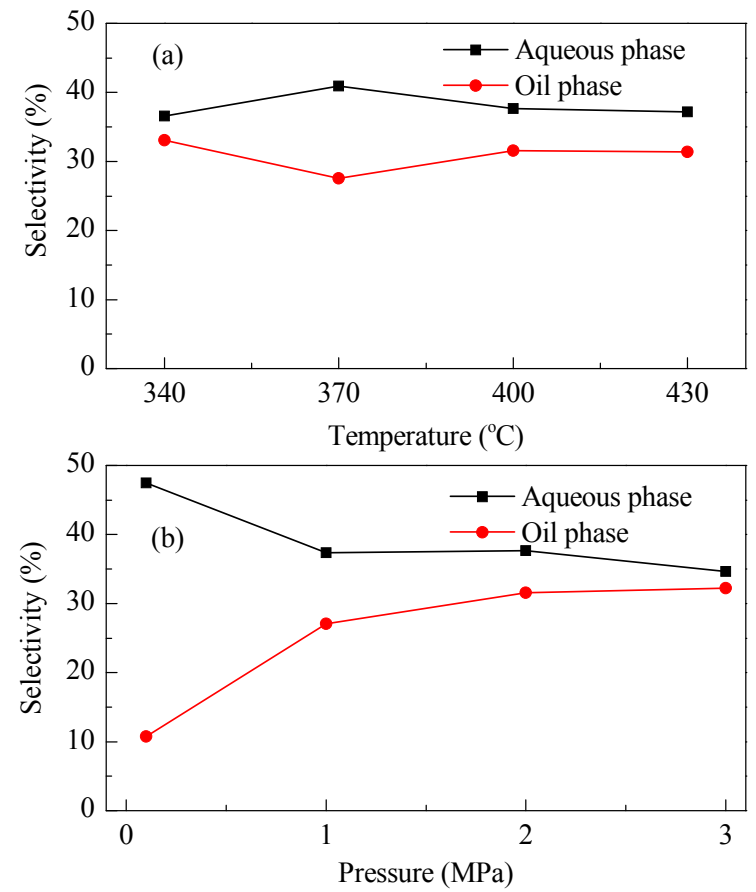

Fig. 3. Reactant selectivities under different reaction conditions: (a) 2 $\mathrm{MPa}$; (b) $400^{\circ} \mathrm{C}$.

on these selectivity variations, we conclude that reaction temperatures above $400{ }^{\circ} \mathrm{C}$ are not only conducive to complete conversion of the reactants but also favor oil phase formation. A comparison of the oil phase selectivity in co-cracking of individual ketones (HPO or CPO) with alcohols, which was around $31.8 \%[23,24]$, showed that the addition of HOAc did not affect the oil phase selectivity. This showed that HOAc also has good capacity for oil phase generation. This is because HOAc is first cracked to produce acetone, followed by acetone condensation and deoxygenation to produce hydrocarbons [17].

The liquid product selectivities at $400{ }^{\circ} \mathrm{C}$ and different reaction pressures are shown in Fig. 3(b). At atmospheric pressure, the oil phase selectivity was only $10.8 \%$, and the product was dark brown, whereas the aqueous phase selectivity was $47.5 \%$. Under pressurized conditions, the oil phase selectivities reached $27.1 \%, 31.5 \%$, and $32.2 \%$ at 1,2 , and $3 \mathrm{MPa}$, respectively. This demonstrated that pressurized conditions could also promote oil phase formation.

\subsubsection{Oil phase composition}

The oil phase composition at $400{ }^{\circ} \mathrm{C}$ and $2 \mathrm{MPa}$ is shown in Fig. 4. This oil phase consisted mainly of aromatic hydrocarbons with carbon numbers in the range 7-10; these are also important components of commercial gasoline. To enable a clear comparison of the compositions of the oil phases obtained under different conditions to be made, the compounds in the oil phase are classified into aromatics, aliphatics, ketones, ethers, and esters. The results are summarized in Fig. 5 ; " $340{ }^{\circ} \mathrm{C} / 2$ $\mathrm{MPa}$ " refers to co-cracking of the model compound mixture and EtOH at $340{ }^{\circ} \mathrm{C}$ and $2 \mathrm{MPa}$.

Figure 5(a) shows the oil phase compositions at different temperatures. At 400 and $430{ }^{\circ} \mathrm{C}$, the oil phase contained high contents of hydrocarbons, greater than $99 \%$. The hydrocarbons were mainly $\mathrm{C}_{7}-\mathrm{C}_{10}$ aromatic hydrocarbons, including toluene, xylene, and methyl-ethyl-benzenes. When the reaction temperature was lower than $400{ }^{\circ} \mathrm{C}$, oxygenated byproducts were generated. Under the conditions $340{ }^{\circ} \mathrm{C} / 2 \mathrm{MPa}$, the content of oxygenated compounds in the oil phase was $40.2 \%$, and the content of oxygenated byproducts reached $18.2 \%$ using the conditions $370{ }^{\circ} \mathrm{C} / 2 \mathrm{MPa}$. The main oxygenated byproducts were ketones, ethers, esters, and other alcohols. The molecular structures of these oxygenated byproducts suggest that the large-molecule ketones were mainly derived from aldol condensation reactions between HPO, CPO, and acetone [23,26]. The ether content was also high, mainly produced by EtOH etherification. Esters, in particular ethyl acetate, were typical products of the esterification of HOAc and EtOH. To ensure complete deoxygenation of the model compound mixture and $\mathrm{EtOH}$, a reaction temperature above $400{ }^{\circ} \mathrm{C}$ is necessary. As the reaction temperature increased, the aromatic hydrocarbon content in the oil phase also increased. This indicates that raising the reaction temperature could promote aromatization reactions; this has also been observed by other researchers [17].

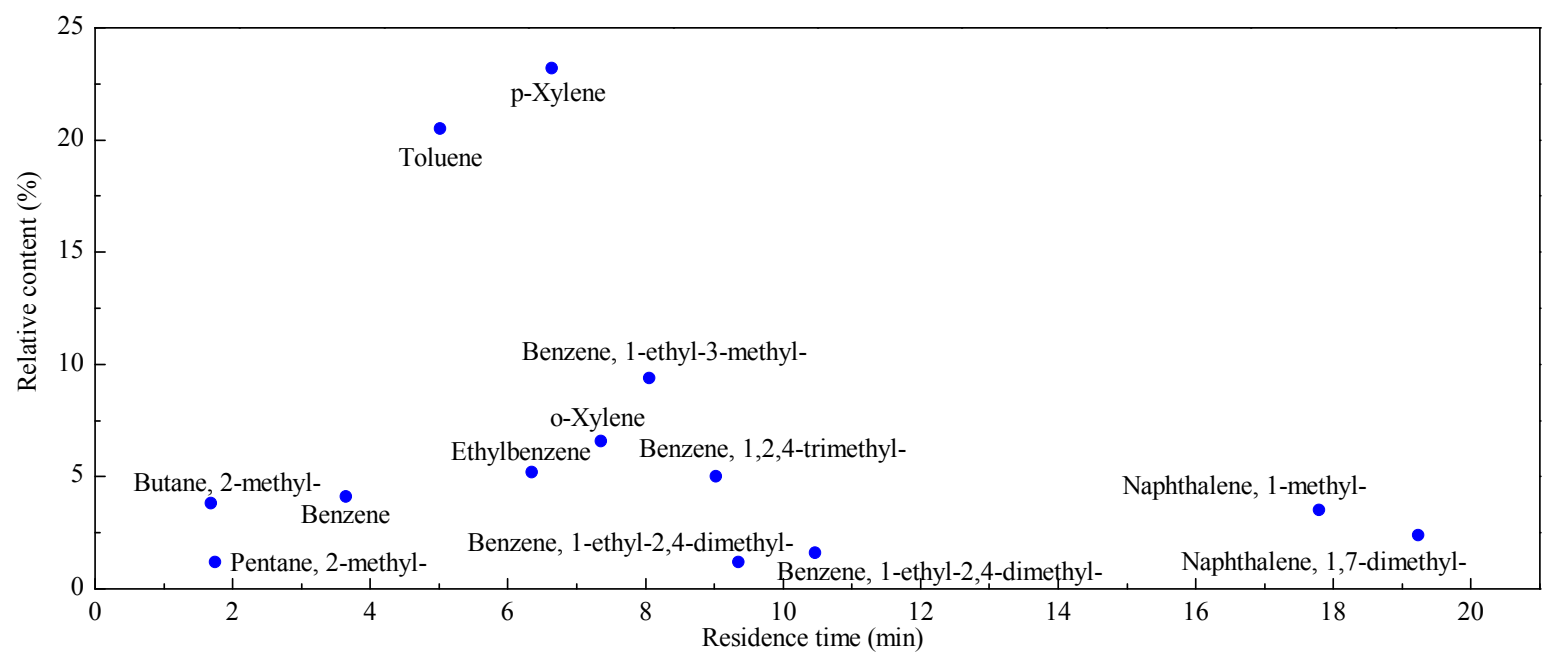

Fig. 4. Oil phase composition at $400{ }^{\circ} \mathrm{C}$ and $2 \mathrm{MPa}$. 

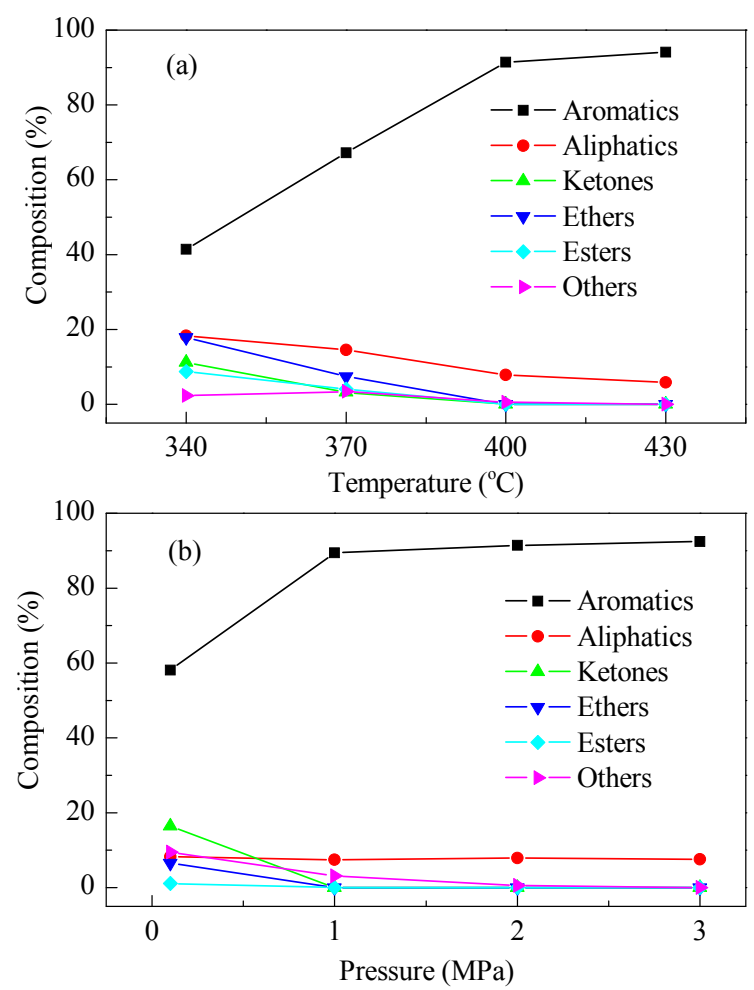

Fig. 5. Oil phase compositions under different reaction conditions: (a) 2 MPa; (b) $400^{\circ} \mathrm{C}$.

The oil phase from co-cracking of the model compound mixture and EtOH had a high content of aromatic hydrocarbons, implying that the reactants might be converted by a double-route transformation mechanism, as proposed in our previous study $[23,24]$. In the first direct-cracking route, HPO, CPO, and acetone from the primary cracking of HOAc undergo aldol condensation and subsequent decarbonylation, decarboxylation, and dehydration reactions to form olefins, $\mathrm{H}_{2} \mathrm{O}$, and $\mathrm{CO}_{x}$, and then the olefins undergo further polymerization to form hydrocarbon products $[17,26]$. The second mechanism, the "hydrocarbon pool" mechanism, is associated with active intermediates such as methyl-substituted benzenes (such as toluene and xylene) $[27,28]$. HPO, CPO, and the intermediate acetone first undergo hydrogen transfer and molecular reforming on the zeolite acidic sites to form enol intermediates containing hydroxyl groups [25]. The enol intermediates and EtOH then react with the active intermediates and are deoxygenated, forming $\mathrm{H}_{2} \mathrm{O}$ and olefins, which ultimately undergo aromatization to generate aromatic hydrocarbons $[27,28]$.

The oil phase compositions at different reaction pressures are shown in Fig. 5(b). The total hydrocarbon contents in the oil phase at $400{ }^{\circ} \mathrm{C} / 1 \mathrm{MPa}, 400{ }^{\circ} \mathrm{C} / 2 \mathrm{MPa}$, and $400{ }^{\circ} \mathrm{C} / 3 \mathrm{MPa}$ were above $97 \%$, and the contents of the corresponding aromatics reached $89.5 \%, 91.5 \%$, and $92.4 \%$, respectively. However, the hydrocarbon content in the oil phase using conditions $400{ }^{\circ} \mathrm{C} / 0.1 \mathrm{MPa}$ decreased significantly, to $66.3 \%$. Along with low oil phase selectivity, the yield of liquid hydrocarbons was very low. The influence of pressure is related to the reaction equilibrium. Light olefins such as $\mathrm{C}_{2} \mathrm{H}_{4}$ are important intermediates in bio-oil cracking $[19,29]$. In the aromatization reac- tions, where light olefins are converted to liquid hydrocarbons, the total stoichiometric number of the products is smaller than that of the reactants. When the pressure increases, the reaction equilibrium therefore moves to the right, which facilitates the conversion of light olefins to liquid hydrocarbons. When the reaction pressure is increased to 2-3 $\mathrm{MPa}$, as a result of limitation of the catalytic capability of the catalyst, the effect of pressure on the reaction equilibrium is not so obvious, so the hydrocarbon selectivity remains constant.

\subsubsection{Vent gas composition}

The vent gas compositions under different conditions are shown in Table 1. The general distribution of gaseous products shows that the vent gases generated using good reaction conditions $\left(400{ }^{\circ} \mathrm{C} / 2 \mathrm{MPa}, 430{ }^{\circ} \mathrm{C} / 2 \mathrm{MPa}, 400{ }^{\circ} \mathrm{C} / 1 \mathrm{MPa}\right.$, and 400 ${ }^{\circ} \mathrm{C} / 3 \mathrm{MPa}$ ) all had high contents of $\mathrm{CO}_{x}$ and $\mathrm{C}_{3} \mathrm{H}_{8}$. A high concentration of $\mathrm{CO}_{x}$ in the vent gas indicates extensive decarbonylation and decarboxylation reactions, which are beneficial for the removal of oxygen; $\mathrm{C}_{3} \mathrm{H}_{8}$, a saturated light hydrocarbon, might come from an aromatization reaction, in which light olefins are converted to highly unsaturated aromatics. As the reaction temperature or pressure decreased, the concentration of $\mathrm{CO}_{x}$ in the vent gas decreased, indicating that deoxygenation reactions such as decarbonylation and decarboxylation were suppressed, and more oxygenated byproducts were produced. In addition, the concentration of $\mathrm{C}_{2} \mathrm{H}_{4}$ in the vent gas increased significantly when the reaction temperature or pressure dropped, suggesting that a lower temperature or pressure suppressed aromatization reactions, and intermediate olefins were released instead of being involved in aromatization reactions to form liquid hydrocarbons. This is in good agreement with the lower oil phase selectivity at lower reaction temperature or pressure.

\subsection{Characterization of spent catalysts}

Catalyst stability is important in catalytic cracking processes, and the main cause of catalyst deactivation is coke formation. The spent catalysts were characterized by $\mathrm{N}_{2}$ physical adsorption and thermogravimetric analysis. The textual properties and coke analysis of the spent catalysts are listed in Table 2.

After reaction for $3 \mathrm{~h}$, the specific surface areas of the spent catalysts all decreased compared with the blank HZSM-5 catalyst, which has a high specific surface area of $340.0 \mathrm{~m}^{2} / \mathrm{g}$. Gen-

\section{Table 1}

Vent gas compositions under different conditions (\%).

\begin{tabular}{lrrrrrrrrr}
\hline Conditions & \multicolumn{1}{c}{$\mathrm{CO}$} & $\mathrm{CO}_{2}$ & $\mathrm{CH}_{4}$ & $\mathrm{C}_{2} \mathrm{H}_{4}$ & $\mathrm{C}_{2} \mathrm{H}_{6}$ & $\mathrm{C}_{3} \mathrm{H}_{6}$ & $\mathrm{C}_{3} \mathrm{H}_{8}$ & $\mathrm{C}_{4} \mathrm{H}_{8}$ & $\mathrm{C}_{4} \mathrm{H}_{10}$ \\
\hline $340{ }^{\circ} \mathrm{C} / 2 \mathrm{MPa}$ & 1.6 & 1.8 & 0.1 & 89.1 & 0.4 & 3.1 & 3.4 & 0.1 & 0.5 \\
$370^{\circ} \mathrm{C} / 2 \mathrm{MPa}$ & 4.5 & 5.4 & 0.5 & 69.0 & 2.3 & 5.1 & 11.3 & 0.6 & 1.3 \\
$400^{\circ} \mathrm{C} / 2 \mathrm{MPa}$ & 16.4 & 15.3 & 1.8 & 3.4 & 8.5 & 1.8 & 40.5 & 10.1 & 2.2 \\
$430^{\circ} \mathrm{C} / 2 \mathrm{MPa}$ & 19.7 & 15.2 & 4.1 & 0.2 & 10.5 & 0.2 & 38.4 & 8.2 & 3.5 \\
$400^{\circ} \mathrm{C} / 0.1 \mathrm{MPa}$ & 1.2 & 1.1 & 0.1 & 88.6 & 0.8 & 7.8 & 0.0 & 0.1 & 0.4 \\
$400^{\circ} \mathrm{C} / 1 \mathrm{MPa}$ & 12.7 & 13.3 & 1.9 & 2.9 & 8.0 & 2.4 & 38.4 & 14.4 & 5.9 \\
$400^{\circ} \mathrm{C} / 3 \mathrm{MPa}$ & 19.5 & 15.4 & 3.0 & 0.5 & 9.4 & 0.4 & 38.9 & 9.2 & 3.8 \\
\hline
\end{tabular}


Table 2

Textural properties and coke analysis of catalyst.

\begin{tabular}{lrccc}
\hline Conditions & $\begin{array}{c}S_{\text {BET }} \\
\left(\mathrm{m}^{2} / \mathrm{g}\right)\end{array}$ & $\begin{array}{c}\text { Pore volume } \\
\left(\mathrm{cm}^{3} / \mathrm{g}\right)\end{array}$ & $\begin{array}{c}\text { Pore size } \\
(\mathrm{nm})\end{array}$ & C/Cat \\
\hline $400^{\circ} \mathrm{C} / 2 \mathrm{MPa}$ & 95.5 & 0.11 & 5.42 & 0.15 \\
$430^{\circ} \mathrm{C} / 2 \mathrm{MPa}$ & 101.9 & 0.12 & 5.21 & 0.15 \\
$370^{\circ} \mathrm{C} / 2 \mathrm{MPa}$ & 75.9 & 0.08 & 5.89 & 0.16 \\
$340^{\circ} \mathrm{C} / 2 \mathrm{MPa}$ & 70.6 & 0.08 & 6.02 & 0.18 \\
$400^{\circ} \mathrm{C} / 3 \mathrm{MPa}$ & 103.0 & 0.14 & 5.32 & 0.14 \\
$400^{\circ} \mathrm{C} / 1 \mathrm{MPa}$ & 89.4 & 0.09 & 5.66 & 0.14 \\
$400^{\circ} \mathrm{C} / 0.1 \mathrm{MPa}$ & 40.9 & 0.07 & 6.38 & 0.18 \\
Blank & 340.0 & 0.26 & 3.09 & - \\
\hline
\end{tabular}

erally, under conditions that gave gasoline phases of higher selectivity and quality, the corresponding catalyst specific surface areas were higher. For example, the specific surface of the catalyst from $400^{\circ} \mathrm{C} / 2 \mathrm{MPa}$ was $95.5 \mathrm{~m}^{2} / \mathrm{g}$, whereas those from $340{ }^{\circ} \mathrm{C} / 2 \mathrm{MPa}$ and $400{ }^{\circ} \mathrm{C} / 0.1 \mathrm{MPa}$ were 70.6 and $40.9 \mathrm{~m}^{2} / \mathrm{g}$ respectively, showing that the catalytic activity was better maintained under the conditions $400{ }^{\circ} \mathrm{C} / 2 \mathrm{MPa}$. The coke:catalyst ratio (C/Cat), calculated based on the thermogravimetric analysis, showed the same tendency. The $\mathrm{C} / \mathrm{Cat}$ was 0.15 for the conditions $400{ }^{\circ} \mathrm{C} / 2 \mathrm{MPa}$, but those for 340 ${ }^{\circ} \mathrm{C} / 2 \mathrm{MPa}$ and $400{ }^{\circ} \mathrm{C} / 0.1 \mathrm{MPa}$ both reached 0.18 .

In our previous study of co-cracking of $\mathrm{HPO}$ and $\mathrm{EtOH}$, the spent catalysts after reaction for $3 \mathrm{~h}$ were characterized, and the catalyst from co-cracking of 30\% $\mathrm{HPO}$ and $70 \% \mathrm{EtOH}$ under the conditions $400{ }^{\circ} \mathrm{C} / 2 \mathrm{MPa}$ had a specific surface area of $129.3 \mathrm{~m}^{2} / \mathrm{g}$ and a C/Cat of 0.12 . Compared with these results, the catalyst from co-cracking of the model compound mixture and EtOH had a lower specific surface area but a higher C/Cat, indicating that the decrease in the catalytic activity was more severe. The model compound mixture has only a small proportion of CPO, which might have a similar cracking performance to that of HPO, because they both have carbonyl groups, therefore it can be concluded that the more obvious deactivation tendency was the result of the presence of HOAc. As mentioned above, the $(\mathrm{H} / \mathrm{C})_{\text {eff }}$ values of HOAc, HPO, and CPO are $0,0.67$, and 1.2, respectively. Cracking of HOAc, which has a low

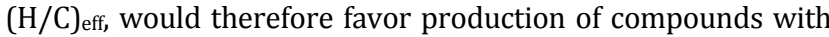
low $(\mathrm{H} / \mathrm{C})_{\text {eff }}$ values, such as coke. In the study carried out by Mentzel et al. [14], in which $10 \%$ HOAc and $10 \%$ acetone, respectively, were cocracked with methanol the catalyst conversion capacities during co-cracking of acetone and methanol were found to be much higher than that of HOAc, indicating that the catalyst lifetime was longer for the co-cracking of acetone and methanol. Coking and catalyst deactivation were therefore higher for cracking of the model compound mixture containing HOAc than those for cracking of individual ketones.

\subsection{Catalyst stability tests}

The catalyst characterization described in Section 3.2 showed that the specific surface area of the catalyst decreased after reaction for $3 \mathrm{~h}$, and some coke formed on the catalyst surface, indicating that the catalytic activity decreased during cracking. The catalyst stability was therefore tested under the conditions $400^{\circ} \mathrm{C} / 2 \mathrm{MPa}$.

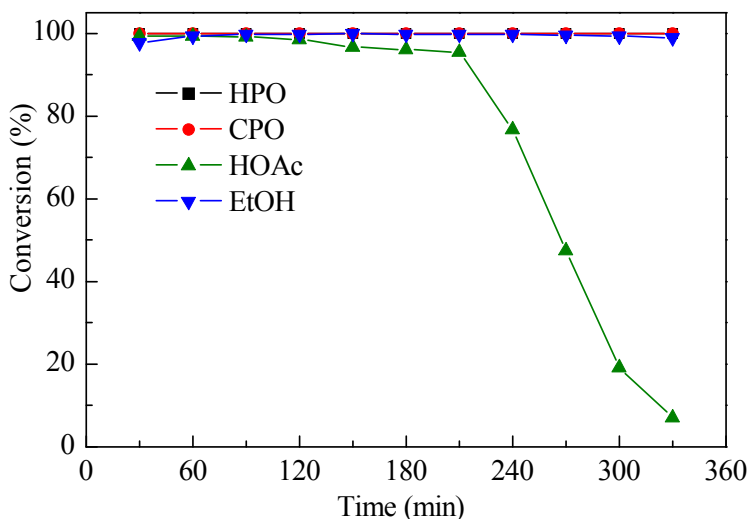

Fig. 6. Reactant conversion as a function of time on stream at $400{ }^{\circ} \mathrm{C} / 2$ $\mathrm{MPa}$

\subsubsection{Reactant conversion}

The changes in reactant conversion as a function of time on stream are presented in Fig. 6. Before $240 \mathrm{~min}$, the four reactants, i.e., HPO, HOAc, CPO, and EtOH, were all converted almost completely. As the reaction continued, the conversion of HOAc began to decrease, from $76.7 \%$ at $240 \mathrm{~min}$ to $7.2 \%$ at $330 \mathrm{~min}$, but the conversions of the other three reactants were still close to $100 \%$. This showed that the decrease in the catalytic activity had a stronger effect on the primary conversion of HOAc than on those of the other reactants, which led to decreased conversion.

\subsubsection{Liquid product selectivity}

Figure 7 shows the changes in liquid product selectivity as a function of time on stream. In the primary stage of cracking, the oil phase selectivity remained at about $31 \%$. It started to drop at $210 \mathrm{~min}$ and reached $3.5 \%$ at $330 \mathrm{~min}$. Compared with the changes in reactant conversion, in which only the HOAc conversion decreased, the decrease in oil phase selectivity occurred earlier, and the changes were greater, showing that the decrease in the catalytic activity had a greater effect on the formation of oil phase products. The main components in the oil phase, i.e., aromatic hydrocarbons, were generated by aromatization, so it can be concluded that the aromatization ca-

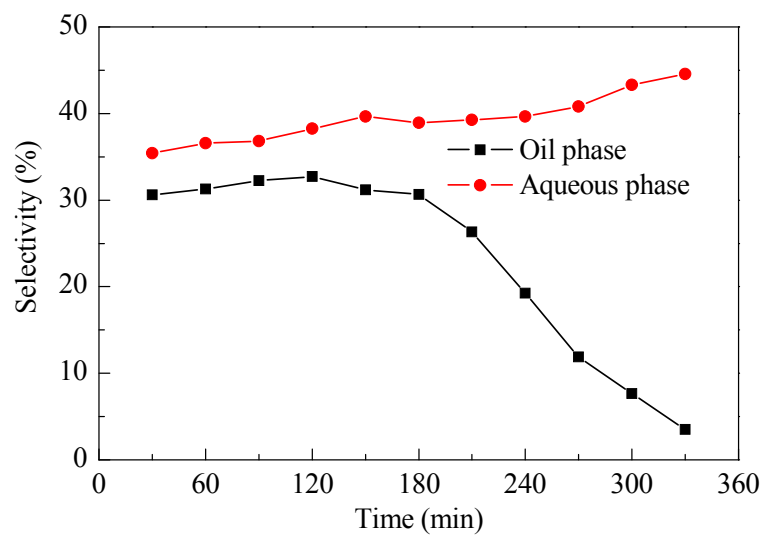

Fig. 7. Liquid product selectivity as a function of time on stream at 400 ${ }^{\circ} \mathrm{C} / 2 \mathrm{MPa}$. 
pacity of the catalyst was first affected when catalyst deactivation started, and the primary conversion capacity of the reactants was affected to a lesser extent. Unlike the case for the oil phase, the aqueous phase selectivity continued to increase slightly even when the catalyst was deactivated; this also indicated that the primary conversion of reactants involving dehydration was not significantly affected.

\subsubsection{Oil phase composition}

The changes in the oil phase composition as a function of time on stream are shown in Fig. 8. Prior to $180 \mathrm{~min}$, the oil phase had a stable composition consisting of about $90 \%$ aromatic hydrocarbons, 9\% aliphatic hydrocarbons, and few oxygenated byproducts. As the reaction continued, accompanied by catalyst deactivation, the aromatic hydrocarbon content decreased, and the aliphatic hydrocarbon and oxygenated byproduct contents both increased. At a reaction time of $330 \mathrm{~min}$, the aromatic hydrocarbon content was only $50 \%$, and the contents of aliphatic hydrocarbons and oxygenated byproducts reached $31.6 \%$ and $18.4 \%$, respectively. The decrease in the aromatic hydrocarbon content reflected the lower aromatization capacity of the catalyst, and the production of larger amounts of oxygenated byproducts, mainly alcohols and ketones, showed a reduction in the deoxygenation efficiency.

\subsubsection{Vent gas composition}

The changes in vent gas composition as a function of time on stream are shown in Fig. 9. In general, the concentrations of the gaseous products except $\mathrm{C}_{2} \mathrm{H}_{4}$ all decreased. In the primary cracking period, the main gaseous products were $\mathrm{C}_{3} \mathrm{H}_{8}, \mathrm{CO}$, and $\mathrm{CO}_{2}$, with concentrations of about $40 \%, 16 \%$, and $15 \%$, respectively. As the catalytic activity decreased, the concentrations decreased to $33.6 \%, 13.9 \%$, and $12.3 \%$ at $210 \mathrm{~min}$. The concentration of $\mathrm{C}_{2} \mathrm{H}_{4}$ increased greatly, from $3 \%$ to $17.9 \%$, at this time. The discussion of the oil phase selectivity in section 3.3.2 showed that the decrease in the oil phase selectivity also began at $210 \mathrm{~min}$, further proving that this decrease was a result of the weaker aromatization capacity of the catalyst, and the intermediate $\mathrm{C}_{2} \mathrm{H}_{4}$ was released instead of participating in the subsequent aromatization reaction. When the reaction time

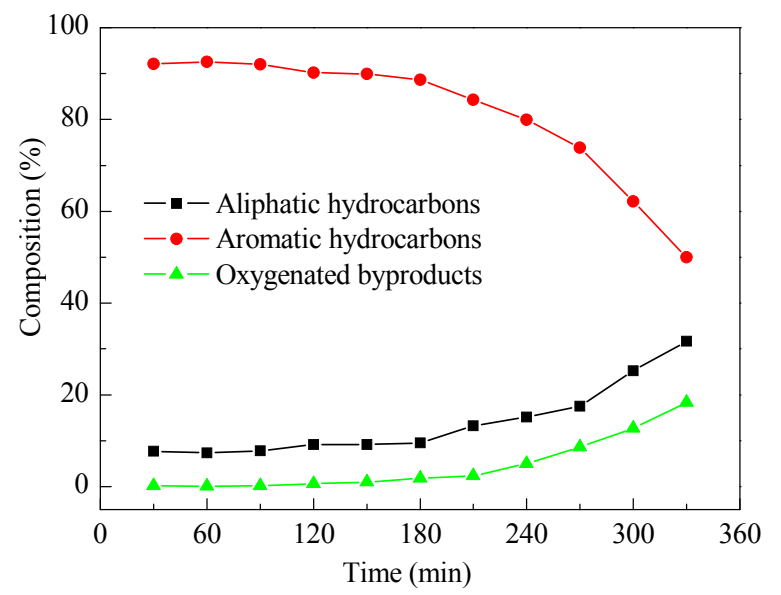

Fig. 8. Oil phase composition as a function of time on stream at 400 ${ }^{\circ} \mathrm{C} / 2 \mathrm{MPa}$.

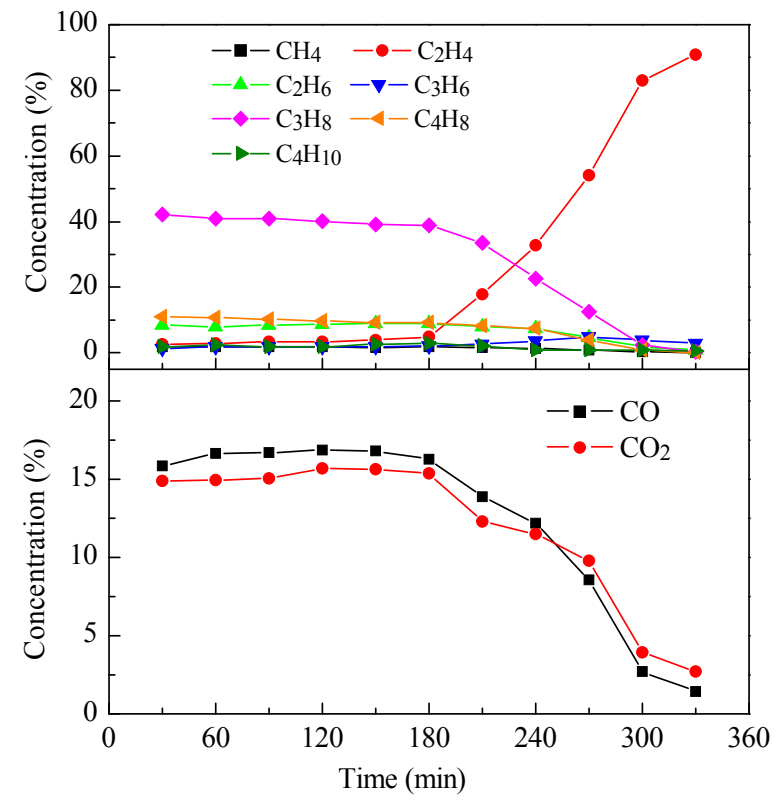

Fig. 9. Vent gas composition as a function of time on stream at $400{ }^{\circ} \mathrm{C} / 2$ MPa. (a) Light hydrocarbons; (b) $\mathrm{CO}_{x}$.

was $330 \mathrm{~min}$, the concentrations of $\mathrm{C}_{3} \mathrm{H}_{8}, \mathrm{CO}$, and $\mathrm{CO}_{2}$ declined to $1.9 \%, 2.4 \%$, and $2.7 \%$, respectively; the concentrations of other gaseous products were lower than $1 \%$, whereas the concentration of $\mathrm{C}_{2} \mathrm{H}_{4}$ was $90.8 \%$. This indicated the low extent of the aromatization reaction, in good agreement with the very low oil phase selectivity of $3.5 \%$ at this point.

\subsection{Catalyst regeneration}

In the catalyst stability tests, the catalytic activity was found to decrease as the reaction proceeded. Catalyst deactivation was mainly caused by coke formation on the catalyst surface, which would cover the active sites and block the inner pores. The spent catalyst after reaction for $4 \mathrm{~h}$ under the conditions $400{ }^{\circ} \mathrm{C} / 2 \mathrm{MPa}$ was regenerated by burning the coke, and the extent of recovery of the catalytic activity was studied. The regeneration temperature was $550{ }^{\circ} \mathrm{C}$ based on the study by Valle et al. [18], and the catalyst was regenerated four times.

\subsubsection{Reactant conversion}

The changes in reactant conversions before and after catalyst regeneration are shown in Fig. 10. During the reaction stage using the fresh catalyst, the conversions of HPO, CPO, and EtOH were close to $100 \%$, but the conversion of HOAc declined to $76.7 \%$ at $240 \mathrm{~min}$. After the first regeneration of the catalyst, the conversion of HOAc returned to above $99 \%$, and the conversions of the other three reactants remained above 99\%. Similarly, in the subsequent continuous reaction, the regenerated catalysts all achieved good recovery of catalytic activity.

\subsubsection{Liquid product selectivity}

The changes in liquid product selectivities before and after catalyst regeneration are shown in Fig. 11. Before the first re- 


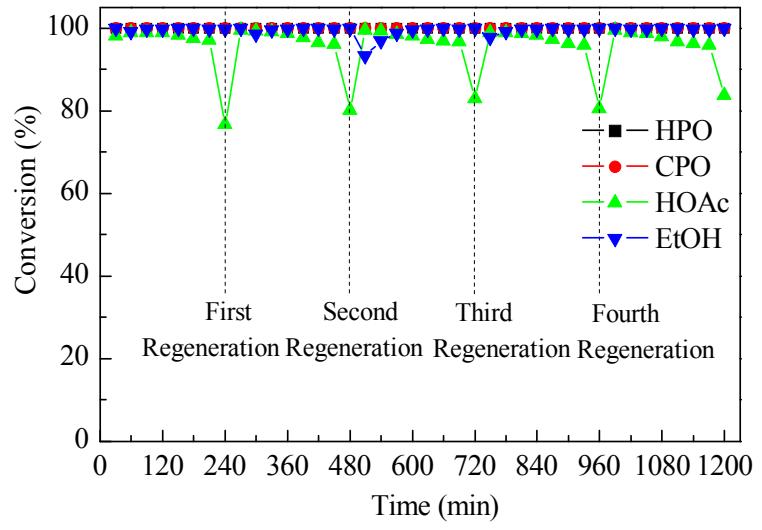

Fig. 10. Reactant conversions before and after catalyst regeneration at $400^{\circ} \mathrm{C} / 2 \mathrm{MPa}$.

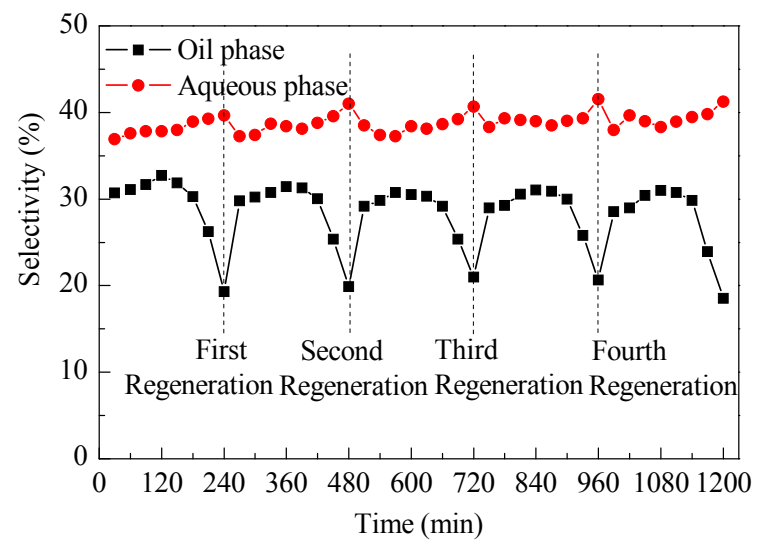

Fig. 11. Liquid-product selectivity before and after catalyst regeneration at $400{ }^{\circ} \mathrm{C} / 2 \mathrm{MPa}$.

generation, the oil phase selectivity dropped from about 31\% at the primary stage to only $19.3 \%$. After catalyst regeneration, the oil phase selectivity was again above $30 \%$. In the subsequent continuous reaction, the catalytic activity recovered well in the regeneration steps and maintained steady generation of the oil phase. In general, the catalyst regeneration extended the catalyst lifetime.

\subsubsection{Oil phase composition}

Figure 12 shows the changes in the oil phase composition before and after catalyst regeneration. Compared with those in the primary stage, the content of aromatic hydrocarbons declined from $92.0 \%$ to $79.1 \%$ at $240 \mathrm{~min}$, and the contents of aliphatic hydrocarbons and oxygenated byproducts rose to $15.2 \%$ and $5.7 \%$, respectively. After catalyst regeneration, the content of aromatic hydrocarbons returned to above $90 \%$, indicating that the aromatization capacity of the catalyst was well recovered by regeneration.

\subsubsection{Vent gas composition}

The catalyst stability tests showed that the concentrations of $\mathrm{CO}, \mathrm{CO}_{2}, \mathrm{C}_{2} \mathrm{H}_{4}$, and $\mathrm{C}_{3} \mathrm{H}_{8}$ changed significantly when the catalyst was deactivated. The concentrations of these four gaseous products before and after catalyst regeneration were therefore monitored; the results are shown in Fig. 13. When the catalyst

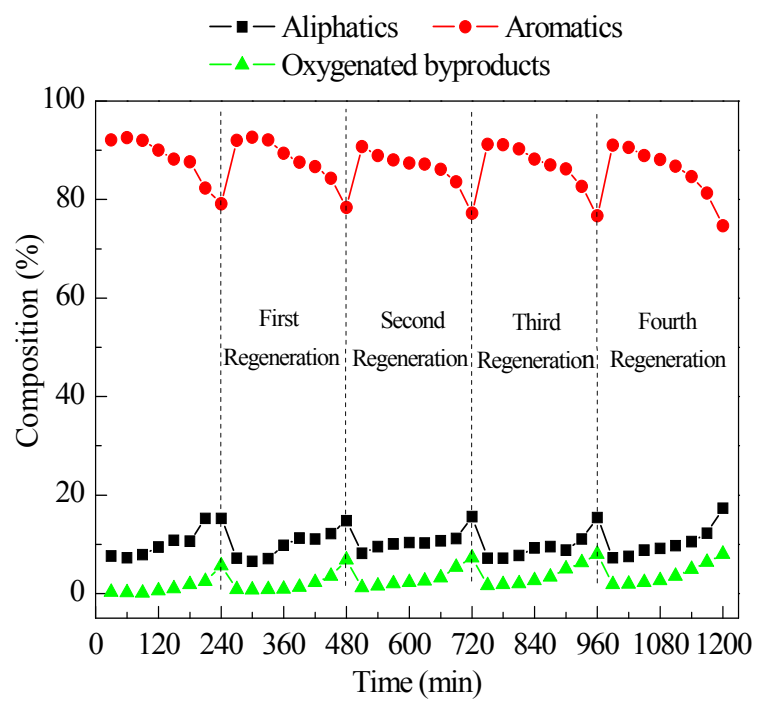

Fig. 12. Oil phase composition before and after catalyst regeneration at $400{ }^{\circ} \mathrm{C} / 2 \mathrm{Mpa}$.

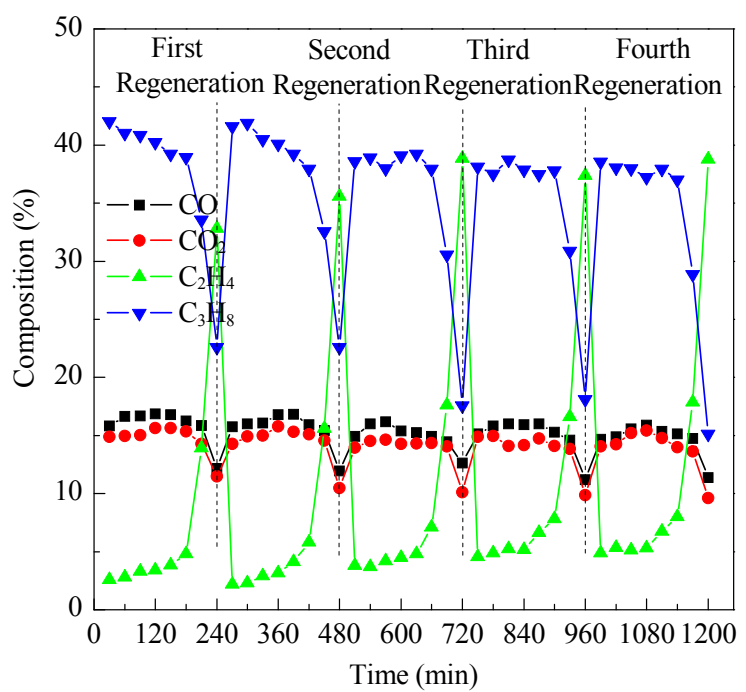

Fig. 13. Vent gas composition before and after catalyst regeneration at $400{ }^{\circ} \mathrm{C} / 2 \mathrm{MPa}$.

was deactivated, the concentrations of $\mathrm{CO}$ and $\mathrm{CO}_{2}$ decreased, and the concentration of $\mathrm{C}_{3} \mathrm{H}_{8}$ decreased greatly from $43 \%$ to $22.6 \%$, whereas the concentration of $\mathrm{C}_{2} \mathrm{H}_{4}$ increased significantly from $2.6 \%$ to $32.6 \%$. After regeneration, the concentration of $\mathrm{C}_{2} \mathrm{H}_{4}$ was below $5 \%$ again, suggesting good recovery of the aromatization capacity, which favored conversion of the intermediate $\mathrm{C}_{2} \mathrm{H}_{4}$ to liquid hydrocarbons.

\section{Conclusions}

The co-cracking performance of mixtures of bio-oil model compounds (HPO, CPO, and $\mathrm{HOAc}$ ) with $\mathrm{EtOH}$ was investigated in a fixed-bed reactor. Higher temperatures and pressures promote conversion of the reactants and generation of liquid hydrocarbons. The optimum reaction conditions were found to be $400{ }^{\circ} \mathrm{C}$ and $2 \mathrm{MPa}$. Under these conditions, acids and ketones were converted completely, and the oil phase selectivity 


\title{
Graphical Abstract
}

Chin. J. Catal., 2014, 35: 709-722 doi: 10.1016/S1872-2067(14)60046-2

\begin{abstract}
Biogasoline production by co-cracking of model compound mixture of bio-oil and ethanol over HSZM-5

Shurong Wang*, Qinjie Cai, Xiangyu Wang, Li Zhang,

Yurong Wang, Zhongyang Luo

Zhejiang University
\end{abstract}

Co-cracking with ethanol using an HZSM-5 catalyst is an efficient method for converting a bio-oil model compound mixture to hydrocarbon fuels.

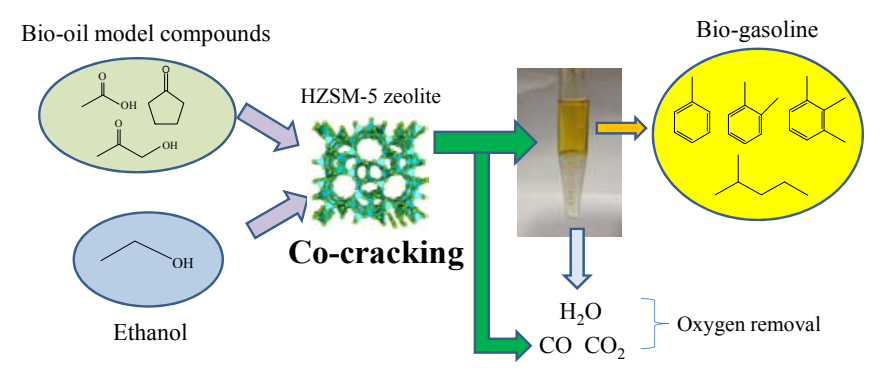

reached $31.5 \mathrm{wt} \%$. This oil phase had a high hydrocarbon content, greater than $99 \%$, and mainly contained $\mathrm{C}_{7}-\mathrm{C}_{9}$ aromatic hydrocarbons such as toluene, xylene, and methyl- and ethyl-substituted benzenes. Characterization of the spent catalysts showed that the specific surface area decreased after cracking, and some coke formed on the catalyst surface. Stability tests also showed that the catalyst was deactivated after 330 min. The catalyst was regenerated by burning the coke and the regeneration achieved good recovery of the catalyst. Because the bio-oil distilled fraction was rich in small-molecule ketones and acids, the successful conversion of ketones and acids to hydrocarbons proves that the co-cracking of actual bio-oil distilled fractions and EtOH is feasible.

\section{References}

[1] Demirbas A. Prog Energy Combust Sci, 2007, 33: 1

[2] Gu H Y, Zhang K, Wang Y D, Huang Y, Hewitt N, Roskilly A P. J Energy Chem, 2013, 22: 413

[3] Li Q Y, Ji S F, Hu J Y, Jiang S. Chin J Catal (李庆远, 季生福, 胡金勇, 蒋 赛. 催化学报), 2013, 34: 1462

[4] Ozbay N, Apaydin-Varol E, Burcu Uzun B, Eren Putun A. Energy, 2008, 33: 1233

[5] Tan S, Zhang Z J, Sun J P, Wang Q W. Chin J Catal (谭顺, 张志军, 孙 建平, 王清文. 催化学报), 2013, 34: 641

[6] Wang C, Hao Q L, Lu D Q, Jia Q Z, Li G J, Xu B. Chin J Catal (王昶, 郝 庆兰, 卢定强, 贾青竹, 李桂菊, 许博. 催化学报), 2008, 29: 907

[7] Czernik S, Bridgwater A V. Energy Fuels, 2004, 18: 590

[8] Zhang Q, Chang J, Wang T J, Xu Y. Energy Convers Manage, 2007, 48: 87

[9] Gong F Y, Yang Z, Hong C G, Huang W W, Ning S, Zhang Z X, Xu Y, Li QX. Bioresource Technol, 2011, 102: 9247

[10] Graça I, Lopes J M, Cerqueira H S, Ribeiro M F. Ind Eng Chem Res, 2013, 52: 275
[11] Adjaye J D, Katikaneni S P R, Bakhshi N N. Fuel Process Technol, 1996, 48: 115

[12] Wang W Y, Zhang X Z, Yang Y Q. Chin J Catal (王威燕, 张小哲, 杨运 泉, 杨彦松, 彭会左, 刘文英. 催化学报), 2012, 33: 215

[13] Guo Z G, Wang S R, Xu G H, Cai Q J. BioResources, 2011, 6: 2539

[14] Mentzel U V, Holm M S. Appl Catal A, 2011, 396: 59

[15] Vitolo S, Seggiani M, Frediani P, Ambrosini G, Politi L. Fuel, 1999, 78: 1147

[16] Gayubo A G, Aguayo A T, Atutxa A, Aguado R, Bilbao J. Ind Eng Chem Res, 2004, 43: 2610

[17] Gayubo A G, Aguayo A T, Atutxa A, Aguado R, Olazar M, Bilbao J. Ind Eng Chem Res, 2004, 43: 2619

[18] Valle B, Gayubo A G, Aguayo A T, Olazar M, Bilbao J. Energy Fuels, 2010, 24: 2060

[19] Guo Z G, Wang S R, Gu Y L, Xu G H, Li X, Luo Z Y. Sep Purif Technol, 2010, 76: 52

[20] Wang S R, Gu Y L, Liu Q, Yan Y, Guo Z G, Luo Z Y, Cen K F. Fuel Process Technol, 2009, 90: 738

[21] Guo X J, Wang S R, Guo Z G, Liu Q, Luo Z Y, Cen K F. Appl Energy, 2010, 87: 2892

[22] Mortensen P M, Grunwaldt J D, Jensen P A, Knudsen K G, Jensen A D. Appl Catal A, 2011, 407: 1

[23] Wang S R, Cai Q J, Wang X Y, Guo Z G, Luo Z Y. Fuel Process Technol, 2013, 111: 86

[24] Wang S R, Cai Q J, Guo Z G, Wang Y R, Wang X Y. BioResources, 2012, 7: 5019

[25] Huang J, Long W, Agrawal P K, Jones C W. J Phys Chem C, 2009, 113: 16702

[26] Cruz-Cabeza A J, Esquivel D, Jimenez-Sanchidrian C, RomeroSalguero F J. Materials, 2012, 5: 121

[27] Haw J F, Song W G, Marcus D M, Nicholas J B. Acc Chem Res, 2003, 36: 317

[28] Olsbye U, Bjorgen M, Svelle S, Lillerud K P, Kolboe S. Catal Today, 2005, 106: 108

[29] Adjaye J D, Bakhshi N N. Biomass Bioenergy, 1995, 8: 131

\section{生物油酸酮类模化物与乙醇在HZSM-5 上共裂化制备生物汽油}

\author{
王树荣”, 蔡勤杰, 王相宇, 张力, 王誉蓉, 骆仲決
} 浙江大学能源清洁利用国家重点实验室, 浙江杭州 310027

摘要: 生物油中酸类和酮类化合物具有较高的裂化活性, 而使用分子蒸馏技术能将这些组分富集到蒸出馏分中, 因此蒸出馏分相 比原始生物油具有更好的裂化特性. 为了模拟实际蒸出馏分的组成, 本文将生物油模化物(羟基丙酮(HPO)、环戊酮和乙酸)进行配 
比混合, 在固定床反应器上对其与乙醇的共裂化行为进行了研究, 考察了不同反应温度和压力对混合反应物的转化率、粗汽油相 的选择性和组成的影响. 研究发现, 当反应温度在 $340{ }^{\circ} \mathrm{C}$ 时, 乙酸和乙醇的转化率分别仅为 $67.9 \%$ 和 $74.4 \%$, 同时得到的油相产物 中烃类含量仅为 $59.8 \%$, 并含有大量的含氧副产物. 常压裂化同样生成了低品质的油相产物, 同时油相选择性仅为 $10.8 \%$. 提高反 应温度能促进反应物的转化, 提高裂化过程中的脱氧效率, 而提高反应压力对液体烃类的生成有明显的促进作用. 在 $400{ }^{\circ} \mathrm{C}$ 和 2 $\mathrm{MPa}$ 时, 酸类和酮类都有良好的裂化表现, 反应物接近完全转化, 粗汽油相选择性达到 $31.5 \%$, 且全部由烃类组成, 其中芳香烃含量 高达 $91.5 \%$. 此外, 反应后催化剂表征和稳定性测试结果表明, 催化剂在较长时间反应后会失活,但通过催化剂再生能够很好地恢 复催化剂活性.

关键词: 生物油; 分子蒸馏; 混合模化物; 催化裂化; 生物汽油

收稿日期: 2013-12-05. 接受日期: 2014-01-22. 出版日期: 2014-05-20.

*通讯联系人. 电话: (0571) 87952801; 传真: (0571) 87951616; 电子信箱: srwang@zju.edu.cn

基金来源：国家自然科学基金(51276166); 国家重点基础研究发展计划(973计划, 2013CB228101); “十二五”国家科技支撑计划 (2011BAD22B06); 浙江省杰出青年科学基金(R1110089); 新世纪优秀人才支持计划(NCET-10-0741).

本文的英文电子版由Elsevier出版社在ScienceDirect上出版(http://www.sciencedirect.com/science/journal/18722067).

\section{1. 前言}

随着化石能源日渐短缺和环境问题日趋严重, 生物 质以其可再生和低污染等特性而备受关注 ${ }^{[1-3]}$. 在众多 生物质利用技术中, 快速热裂解具有较大潜力, 它能高 效地将固态生物质转化为能量密度高、易运输、易储存 的液态生物油 ${ }^{[4-6]}$. 但是生物油的低热值、高含氧量、高 水分含量和热不稳定性等燃料特性上的不足阻碍了其 高品位利用 ${ }^{[7]}$.

品位提升工艺是克服生物油以上不足的一个重要 环节, 它包括催化加氢、催化裂化、水蒸气催化重整、 催化酯化和乳化等 ${ }^{[8]}$. 其中, 催化裂化 ${ }^{[9-12]}$ 可通过催化剂 将生物油中的氧元素以 $\mathrm{H}_{2} \mathrm{O}, \mathrm{CO}$ 和 $\mathrm{CO}_{2}$ 等形式脱除, 使 生物油转变为高品位液体烃类产物, 大大降低生物油含 氧量和粘度, 同时提高生物油稳定性和热值, 是未来较 有潜力的生物油品位提升方法.

生物油组成复杂, 富含酸、醛、酮、醇、酚、酯、 醚和糖等各种含氧化合物 ${ }^{[13,14]}$. 因此, 以全组分生物油 为原料进行裂化时, 虽能得到一定品质的液体烃类燃料, 但是在裂化过程中存在较为严重的结焦堵塞及催化剂 失活问题 ${ }^{[15]}$. 为了深入探究生物油中各组分裂化机理, 研究者对生物油不同族类模化物的裂化行为进行了研 究, 发现醇、酸和酮等小分子物质具有较高的裂化活性, 而酚类等反应活性较低 ${ }^{[16,17]}$. 同时, 生物油中大分子的 糖类和酚类聚合物在进入催化床层后很容易沉积并形 成焦炭 ${ }^{[18]}$.

因此, 为了提高生物油组分的裂化效率, 首先要实 现生物油中适宜裂化组分的富集. 结合分子蒸馏技术, 可以实现热敏性生物油的高效分离, 获得相应的生物油 蒸出馏分和残余馏分. 在我们前期对生物油的分子蒸馏 特性研究中发现, 蒸出馏分富集了生物油中的酮类和酸
类等小分子化合物, 如羟基丙酮(HPO), 环戊酮(CPO)和 乙酸 $(\mathrm{HOAc})$ 同时大分子的糖类和酚类得到了良好脱 除 ${ }^{[19-21]}$. 因此, 生物油蒸出馏分与原始生物油相比具有 更好的裂化表现.

尽管生物油蒸出馏分的裂化特性优于原始生物油, 但其直接裂化仍存在结焦问题, 主要原因是蒸出馏分仍 具有较高的含氧量和不饱和度. 在生物油催化裂化的研 究中, 一些研究者通过引入有效氢碳比 $(\mathrm{H} / \mathrm{C})_{\mathrm{eff}}$ 的概念来 评估生物油中含氧量和不饱和度对催化剂寿命的影 响 ${ }^{[14,22]}$, 公式为 $(\mathrm{H} / \mathrm{C})_{\mathrm{eff}}=(\mathrm{H}-2 \mathrm{O}-3 \mathrm{~N}-2 \mathrm{~S}) / \mathrm{C}$. Mentzel等 ${ }^{[14]}$ 发现催化剂更容易在低 $(\mathrm{H} / \mathrm{C})_{\mathrm{eff}}$ 化合物裂化过程中失活. 因此, 可以推断生物油中较高含氧量和不饱和度导致的 较低的 $(\mathrm{H} / \mathrm{C})_{\mathrm{eff}}$, 是导致裂化过程中催化剂失活的主要原 因.

通过上式计算生物油馏分油典型模化物的 $(\mathrm{H} / \mathrm{C})_{\mathrm{eff}}$ 发现, 美基丙酮仅为 0.67 , 环戊酮仅为 1.2 , 乙酸为 0 . 故这 几种生物油模化物在反应过程中较容易形成积炭造成 催化剂失活. 因此, 需要加入一些具有相对较高 $(\mathrm{H} / \mathrm{C})_{\mathrm{eff}}$ 的化合物进行共裂化, 通过提高裂化过程反应物的整体 $(\mathrm{H} / \mathrm{C})_{\mathrm{eff}}$ 来提高反应的稳定性. 醇类具有相对较高的 $(\mathrm{H} / \mathrm{C})_{\mathrm{eff}}$ 、良好的稳定性和溶解性, 是一种理想的共裂化 溶剂. Mentzel等 ${ }^{[14]}$ 研究了甲醇和生物油模化物的共裂 化, 发现催化剂寿命明显提高, 其转化能力达到原来的 10 倍以上. Valle等 ${ }^{[18]}$ 使用热处理后的生物油与甲醇共 裂化, 同样使反应稳定性得到提高. 我们之前研究了生 物油酮类模化物(环戊酮和羟基丙酮)与醇类的共裂化, 获得了高品质的汽油相产物, 同时催化剂的稳定性较好

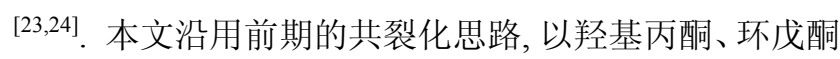
与乙酸为主要研究对象, 将它们按照在生物油蒸出馏分 中的分布进行配比来模拟实际蒸出馏分, 并以乙醇为共 裂化反应物, 研究它们的共裂化行为, 考察温度和压力 
对裂化产物选择性和组成的影响, 寻找反应最适宜工况.

\section{2. 实验部分}

羟基丙酮购自阿法埃莎公司, 环戊酮购自阿拉丁公 司, 乙酸和乙醇购自国药化试公司买. 前期研究发现, 使 用 $70 \%$ 乙醇掺混到酮类模化物中进行共裂化能高效生 成汽油相产物 ${ }^{[24]}$. 因此, 本实验继续采用 $70 \%$ 乙醇和 $30 \%$ 混合模化物配比. 同时, 基于羟基丙酮、环戊酮和乙 酸在原始生物油中的含量及其分子蒸馏分离特性 ${ }^{[19-21]}$, 混合模化物中羟基丙酩: 环戊酮:乙酸 $=6: 1: 5$, 即 $15 \%$ 差 基丙酮, $2.5 \%$ 环成酮和 $12.5 \%$ 乙酸. 使用的催化剂为 HZSM-5( $\mathrm{Si} / \mathrm{Al}=25)$ 分子篎. HZSM-5催化剂在反应前以 $5{ }^{\circ} \mathrm{C} / \mathrm{min}$ 的速率升温至 $550{ }^{\circ} \mathrm{C}$ 活化 $6 \mathrm{~h}$, 并篮分至 40-60 目.

裂化实验在固定床反应器上进行, 装填 $2 \mathrm{~g}$ 的催化剂 到内径为 $8 \mathrm{~mm}$ 的不锈钢管里, 用石英棉支撑. 反应物通 过HPLC泵输送给料, 经汽化后与载气 $\mathrm{N}_{2}$ 一起进入反应 器中, 反应压力由 $\mathrm{N}_{2}$ 维持, 其流量为 $30 \mathrm{~mL} / \mathrm{min}$. 反应物 的质量空速(WHSV) 恒定为 $3 \mathrm{~h}^{-1}$. 反应器出口气体经冷 凝器冷却, 得到液体产物和不可冷凝的气体. 单次工况 运行 $3 \mathrm{~h}$, 研究的反应温度为 $340-430{ }^{\circ} \mathrm{C}$, 反应压力为 0.1-3 MPa.

实验获得的产物包括气体和液体产物. 气体产物通 过在线气相色谱(安捷伦7890A)进行定量分析. 裂化液 体产物存在明显的分层, 包括粗汽油相与水相. 粗汽油 相采用气相色谱与质谱联用仪器(GC-MS)进行定性与 面积归一法定量分析. 液体产物(包括粗油相和水相)中 的残余反应物采用气相色谱外标法进行定量, 用于计算 反应物转化率. 液体产物的选择性根据收集到的粗油相 和水相(不包括未转化的反应物)和转化的反应物质量进 行计算.

空白和反应后HZSM-5 催化剂的比表面积通过 $-196{ }^{\circ} \mathrm{C}$ 下的 $\mathrm{N}_{2}$ 物理吸附测定, 使用的设备为Autosorb-1 Quantachrome全自动比表面与孔径分布分析仪.

\section{3. 结果与讨论}

\section{1. 反应温度与压力的影响}

\subsection{1. 反应物转化率}

不同反应温度下模化物混合物与乙醇的转化率如 图1(a)所示. 在 $340{ }^{\circ} \mathrm{C}$ 时, 美基丙酮和环戊酮趋于完全转 化, 而乙酸和乙醇的转化率分别仅有 $67.9 \%$ 和 $74.4 \%$. 这 可能是由于低温下催化剂的催化裂化能力较弱, 同时乙
酸和乙醇分子活性也较低, 导致它们难以完全转化. 在 我们之前对羟基丙䣶与乙醇的共裂化研究中也发现, 在 较低的反应温度下羟基丙酮就有良好的反应活性, 而乙 醇反应活性较低, 但羟基丙酮低温下主要发生的是分子 间脱水缩合生成酮类等含氧副产物 ${ }^{[23]}$. Huang等 ${ }^{[25]}$ 对环 戊酮在酸性分子篮上的转化研究中也发现低温下环戊 酩同样也容易发生缩合形成含氧多聚物. 因此, 尽管酮 类在低温下转化率较高, 但反应可能不是生成目标产物. 低温下乙酸的转化较为困难, Gayubo 等 ${ }^{[17]}$ 发现乙酸裂化 的中间产物丙酮需要在 $400{ }^{\circ} \mathrm{C}$ 左右的反应温度下才开 始大量生成. 当温度增大至 $370{ }^{\circ} \mathrm{C}$ 时, 乙醇转化率大幅 提高到 $89.5 \%$, 乙酸转化率也增加到 $72.8 \%$, 而羟基丙酮 和环戊酮的转化率则略有降低. 这可能是由于温度上升 时乙酸和乙醇的分子活性增加, 但受 $370{ }^{\circ} \mathrm{C}$ 时催化剂催 化能力限制, 与羟基丙酮和环戊酮在催化剂上的转化发 生一定竞争, 使得自身转化率增加而羟基丙酮和环戊酮 的转化率降低. 当反应温度进一步升高至 $400{ }^{\circ} \mathrm{C}$ 及以上 时, 催化剂催化能力提高实现了乙酸和乙醇的顺利活化, 不仅羟基丙酮和环戊酮继续保持较高的转化率, 乙醇和 乙酸也同时接近完全转化. 因此, 为了实现模化物混合 物与乙醇的完全转化, 反应温度需要控制在 $400^{\circ} \mathrm{C}$ 以上.

不同反应压力下模化物混合物与乙醇的转化率如 图1(b)所示. 在 $400{ }^{\circ} \mathrm{C}$ 的反应温度下, 加压时反应物羟基 丙酮、环戊酮、乙酸和乙醇的转化率都达到 $97 \%$ 以上, 且 当压力增加到 $2 \mathrm{MPa}$ 以上时反应物均接近于完全转化; 在常压时, 差基丙醖转化率达到 $100 \%$, 但环戊酮、乙酸 和乙醇转化率却偏低, 分别为 $83.6 \%, 85.6 \%$ 和 $93.1 \%$. 因 此, 保持一定的压力对促进反应物转化是有利的.

\subsection{2. 液体产物选择性}

反应收集到的液体存在着明显的分层现象, 上层为 粗汽油相, 下层为澄清的水相(图2(a)); 且不同工况下汽 油相的颜色也不同(图2(b)).

不同反应温度下液体产物的选择性如图3(a)所示. 当反应温度为 $340{ }^{\circ} \mathrm{C}$ 时, 尽管有 $33.1 \%$ 的粗汽油相选择 性, 但粗汽油相外观呈黄褐色, 即其中可能含有较多的 含氧副产物. 当反应温度升高至 $370^{\circ} \mathrm{C}$ 时, 粗汽油相颜 色开始呈现淡黄褐色, 因此尽管 $370{ }^{\circ} \mathrm{C}$ 时粗汽油相选择 性比 $340{ }^{\circ} \mathrm{C}$ 时有所降低, 为 $27.6 \%$, 但实际烃类选择性可 能较高. 当反应温度升高至 $400{ }^{\circ} \mathrm{C}$ 及以上时, 粗汽油相 的选择性稳定在 $31 \%$ 以上, 且收集到的粗汽油相为淡黄 色, 说明 $400{ }^{\circ} \mathrm{C}$ 以上的反应温度不仅有利于反应物的完 全转化, 还能促进汽油相的有效生成. 与 $400{ }^{\circ} \mathrm{C}$ 时酮类 
(羊基丙酮和环戊酩)分别单独与醇类裂化的粗汽油相产 率(31.9\%和 $31.6 \%$ )相比, 乙酸的添加并未明显影响汽油 相的产率 ${ }^{[23,24]}$. 这说明乙酸也有很好的裂化制备汽油相 的能力, 即乙酸能顺利通过丙酮等中间产物进一步按照 酮类的裂化机理产生烃类 ${ }^{[17]}$.

不同反应压力下液体产物的选择性如图3(b)所示. 常压下粗汽油相的选择性仅为 $10.8 \%$, 且汽油相为深褐 色, 而水相的选择性则高达 $47.5 \%$. 而在加压条件下 $(1,2$ 和 $3 \mathrm{MPa}$ ), 粗汽油相的选择性分别可达 $27.1 \%, 31.5 \%$ 和 $32.2 \%$. 这说明加压对粗汽油相的生成有明显的促进作 用.

\subsection{3. 粗汽油相组成}

$400{ }^{\circ} \mathrm{C} / 2 \mathrm{MPa}$ 工况下粗汽油相的组成如图4所示, 该 汽油相主要由 $\mathrm{C}_{7}-\mathrm{C}_{10}$ 的小分子芳香烃组成, 而这些小分 子芳香烃同时也是市售汽油的主要成分. 为了清楚比较 不同工况下粗汽油相的组成, 对这些裂化产物按照芳香 烃、脂肪烃、酮类、醚类和酯类等进行归类分析, 获得 了如图 5所示的组成信息. 其中 “ $340{ }^{\circ} \mathrm{C} / 2 \mathrm{MPa}$ ”表示模 化物混合物与乙醇在 $340^{\circ} \mathrm{C}$ 和 $2 \mathrm{MPa}$ 下的裂化实验工况.

图5(a)给出了不同反应温度下粗汽油相的组成. 当 反应温度为 400 和 $430{ }^{\circ} \mathrm{C}$ 时, 获得的粗汽油相基本上由 烃类组成, 芳香烃含量分别达到 $91.5 \%$ 和 $94.1 \%$, 组成上 主要是以 $\mathrm{C}_{7}-\mathrm{C}_{10}$ 的小分子液体烃类为主, 包括甲苯、二甲 苯和甲基乙基苯等汽油中的重要组分. 当反应温度低于 $400{ }^{\circ} \mathrm{C}$ 时, 粗汽油中含氧副产物开始生成, 粗汽油品质 下降. $340^{\circ} \mathrm{C} / 2 \mathrm{MPa}$ 工况下得到的粗汽油相中含氧副产 物含量高达 $40.2 \%$, 而在 $370{ }^{\circ} \mathrm{C} / 2 \mathrm{MPa}$ 工况时得到的粗 汽油相中含氧副产物含量也达到 $18.2 \%$. 生成的含氧副 产物主要包括酮类、醚类、酯类及其他醇类等. 从这些 副产物的组成和分子结构来看, 羊基丙酮、环戊酮及乙 酸的中间产物丙酮可能在裂化过程中发生羟醛缩合等 反应形成醚类、醇类、呋喃类和新的结构复杂的酮类 ${ }^{[23,26]}$; 乙酸和乙醇则可能发生典型的酯化反应生成酯 类. 这些副产物的产生主要是由于较低的反应温度影响 了反应物的活性和催化剂的催化能力, 使得脱氧过程不 能完全进行. 因此, $400^{\circ} \mathrm{C}$ 以上的反应温度是保证裂化 反应完全进行所必需的. 同时, 随着反应温度升高, 粗汽 油相中的芳香烃含量不断增大, 表明反应温度与芳构化 程度成正相关, 这也被其他研究者所证实 ${ }^{[17]}$.

模化物混合物与乙醇共裂化反应的汽油相中富含 芳香烃的现象恰好符合了我们在之前研究中提出的反 应物双路径转化(直接裂化和烃池转化)机理 ${ }^{[23,24]}$. 对于
直接裂化反应路径, 反应物羟基丙酮、环戊酮和乙酸初 步裂化生成的丙酮可能发生缩合以及后续的脱羧基、脱 羰基和脱水反应得到烯烃、 $\mathrm{H}_{2} \mathrm{O}, \mathrm{CO}$ 和 $\mathrm{CO}_{2}$, 再由烯烃进 一步聚合得到烃类产物 ${ }^{[17,26]}$. 而烃池转化路径则可能与 汽油相中的甲基取代苯这类活性中间体(如甲苯、二甲 苯和三甲苯等)有关 ${ }^{[28,29]}$. 羟基丙酮、环戊酮和乙酸裂化 中间产物丙酮首先在分子篮酸性位上通过氢键转移和 分子重整转变为含有着基的烯醇类中间结构 ${ }^{[26]}$. 随后, 这些含羟基的中间产物以及共裂化反应物乙醇与活性 中间体发生作用, 并以 $\mathrm{H}_{2} \mathrm{O}$ 的形式脱氧生成烯烃, 并最终 发生芳构化得到芳香烃等产物, 进一步丰富烃类 ${ }^{[27,28]}$.

不同反应压力下粗汽油相组成如图 5(b) 所示. $400{ }^{\circ} \mathrm{C} / 1 \mathrm{MPa} 、 400{ }^{\circ} \mathrm{C} / 2 \mathrm{MPa}$ 和 $400{ }^{\circ} \mathrm{C} / 3 \mathrm{MPa}$ 这三个加压 工况下得到了很好的粗汽油相品质, 烃类含量在 $97 \%$ 以 上, 其中 $400{ }^{\circ} \mathrm{C} / 2 \mathrm{MPa}$ 和 $400{ }^{\circ} \mathrm{C} / 3 \mathrm{MPa}$ 更是达到 $99.5 \%$ 以 上; 相应的芳香烃含量分别为 $89.5 \%$ 、91.5\%和 $92.4 \%$. 而 常压裂化得到的粗汽油相烃类含量降至 $66.3 \%$, 由于实 验中该工况下粗汽油相的选择性很低, 故实际的烃类产 率相当低, 同时还存在一定的酮类和醚类等含氧化合物. 在生物油含氧化合物裂化反应中, 轻质烯烃例如 $\mathrm{C}_{2} \mathrm{H}_{4}$ 是 一种重要的反应中间体 ${ }^{[19,29]}$, 在裂化过程中这些轻质烯 烃会在催化剂作用下转变为液体烃类产物, 而且反应后 气体的分子数减少. 由于增加压力时化学平衡向气体分 子数减小的方向移动, 故增加压力将有利于轻质烯烃向 液体烯烃转变. 当压力增加到2-3 MPa时, 受到催化剂 催化能力的限制, 压力对反应平衡的影响已经不明显, 故烃类的选择性基本保持稳定.

\subsection{4. 气体产物组成}

不同工况下尾气组成如表 1 所示. 从总的气体产物 分布来看, 裂化效果较好的 $400{ }^{\circ} \mathrm{C} / 2 \mathrm{MPa}, 430{ }^{\circ} \mathrm{C} / 2$ $\mathrm{MPa}, 400{ }^{\circ} \mathrm{C} / 1 \mathrm{MPa}, 400{ }^{\circ} \mathrm{C} / 3 \mathrm{MPa}$ 工况尾气中 $\mathrm{CO}_{x}$ 和 $\mathrm{C}_{3} \mathrm{H}_{8}$ 的浓度大多比较高. 较高的 $\mathrm{CO}_{x}$ 浓度说明裂化过程中发 生了高效的脱羧基和脱羰基作用, 这样有利于更多的氢 元素保留在产物中, 提高产物品质和反应过程的稳定性; 而 $\mathrm{C}_{3} \mathrm{H}_{8}$ 为饱和烃, 可能来自于烯烃等中间产物转化为不 饱和度较高的芳香烃的芳构化过程. 随着反应温度和反 应压力降低, 尾气中的 $\mathrm{CO}_{x}$ 浓度也开始降低, 说明脱羰基 和脱羧基等脱氧过程受到抑制, 因此在粗汽油相中观察 到较多含氧化合物的存在. 此外, 随着温度和压力的降 低, $\mathrm{C}_{2} \mathrm{H}_{4}$ 的浓度显著增加, 说明较低的温度和压力导致 催化剂表面的芳构化反应强度较低, 使得这些烯烃中间 产物被释放而不继续参与芳构化等反应形成液体烃类， 
这与低温与低压工况下观察到的较低的液体烃类选择 性相符.

\section{2. 反应后催化剂表征}

对于催化裂化过程, 最重要的问题是催化剂的稳定 性, 导致催化剂失活的主要原因是积炭的形成. 因此, 针 对实验过程中几个典型工况, 我们采用 $\mathrm{N}_{2}$ 物理吸附方法 对反应后的催化剂进行表征, 同时根据热重分析结果计 算了催化剂表面的积炭量, 结果如表2所示.

经过 $3 \mathrm{~h}$ 的催化裂化反应, 相比原始空白HZSM-5催 化剂(比表面积为 $340.0 \mathrm{~m}^{2} / \mathrm{g}$ ), 各个工况反应后的催化剂 比表面积都有不同程度的下降. 总的来看, 对于油相选 择性和品质较高的工况, 如 $400{ }^{\circ} \mathrm{C} / 2 \mathrm{MPa}$, 其反应后的催 化剂具有相对较高的比表面积 $\left(95.5 \mathrm{~m}^{2} / \mathrm{g}\right)$, 而 $340{ }^{\circ} \mathrm{C} / 2$ $\mathrm{MPa}$ 和 $400{ }^{\circ} \mathrm{C} / 0.1 \mathrm{MPa}$ 反应后催化剂的比表面积分别仅 为 70.6 和 $40.9 \mathrm{~m}^{2} / \mathrm{g}$, 说明 $400{ }^{\circ} \mathrm{C} / 2 \mathrm{MPa}$ 工况更利于维持 催化剂的活性. 反应后催化剂表面的焦炭与催化剂的质 量比 (C/Cat) 通过热重分析得到. 经过计算发现, $400{ }^{\circ} \mathrm{C} / 2 \mathrm{MPa}$ 工况反应后的催化剂积炭量相对较小, $\mathrm{C} / \mathrm{Cat}$ 为 0.15 , 而 $340{ }^{\circ} \mathrm{C} / 2 \mathrm{MPa}$ 和 $400{ }^{\circ} \mathrm{C} / 0.1 \mathrm{MPa}$ 反应后催 化剂的 $\mathrm{C} / \mathrm{Cat}$ 都达到 0.18 .

在我们过去对羟基丙酮单独与乙醇共裂化的研究 中, 也对 $400^{\circ} \mathrm{C} / 2 \mathrm{MPa}$ 工况反应 $3 \mathrm{~h}$ 后的HZSM-5催化剂 进行了表征, 结果显示该催化剂比表面积为 $129.3 \mathrm{~m}^{2} / \mathrm{g}$, $\mathrm{C} / \mathrm{Cat}$ 值为 0.12 . 对比羟基丙酮单独与乙醇共裂化的催 化剂, 混合模化物与乙醇共裂化后的催化剂比表面积较 低, 同时积炭量略高, 即催化剂的活性相对下降得更为 明显. 考虑到混合模化物中环戊酮量很少, 并且裂化特 性与同族类的羟基丙酮较为类似, 可以推断混合模化物 裂化过程中催化剂呈现更明显的积炭趋势主要是由于 酸性组分乙酸的存在. 前面已经提到, 乙酸、羟基丙酮和 环戊酮这三种模化物的有效氢碳比分别为 $0,0.67$ 和 1.2 , 因此低有效氢碳比的乙酸更容易在裂化过程中生成低 $\mathrm{H} / \mathrm{C}$ 的最终产物, 如焦炭等, 从而导致催化剂活性下降. Mentzel 等 ${ }^{[14]}$ 在对浓度 $10 \%$ 的乙酸和丙酮分别与甲醇共 裂化的研究中也发现, 在丙酮与甲醇共裂化的过程中催 化剂在失活前的转化能力更高, 即在酮类和甲醇的共裂 化过程中催化剂具有更长的使用寿命. 因此, 相比于单 独羟基丙酩与乙醇的共裂化, 引入酸性组分乙酸的模化 物混合物具有更为明显的积炭和催化剂失活趋势.

\section{3. 催化剂稳定性测试}

前面的催化剂表征结果显示, $3 \mathrm{~h}$ 反应后的催化剂比 表面积下降, 同时催化剂表面有积炭形成, 表明催化剂
在裂化过程中活性会不断降低. 因此, 在 $400{ }^{\circ} \mathrm{C} / 2 \mathrm{MPa}$ 条件下通过连续实验对催化剂的稳定性进行了测试.

\subsection{1. 反应物转化率}

反应物转化率随反应时间的变化如图6所示. 在 210 $\min$ 以前, 乙酸、美基丙酮、环戊酮和乙醇这四种反应物 都基本实现了完全转化. 随着反应进行, 乙酸转化率开 始下降, 从 $240 \mathrm{~min}$ 时的 $76.7 \%$ 降至 $330 \mathrm{~min}$ 时的 $7.2 \%$, 而 其他三种反应物仍然保持了接近 $100 \%$ 的转化率. 这说 明催化剂活性的降低对乙酸在催化剂表面的初步分解 影响更为明显, 导致其转化率下降.

\subsection{2. 液体产物选择性}

液体产物选择性随反应时间的变化如图7所示. 初 始阶段油相产物的选择性稳定在 $31 \%$ 左右, 并从 $210 \mathrm{~min}$ 开始出现下降, 到 $330 \mathrm{~min}$ 时仅为 $3.5 \%$. 与反应物的转化 率相比, 液体产物选择性的下降不仅更早发生, 而且下 降趋势也更为明显 (反应物中仅有乙酸出现了转化率下 降). 这说明催化剂的活性降低对油相产物的形成影响 更大, 考虑到油相产物中的主要组分芳香烃是通过芳构 化作用形成的, 因此推断催化剂的活性降低首先影响了 其芳构化能力, 而对反应物在催化剂表面的初步转化影 响相对较小. 与油相产物相比, 即使催化剂活性下降, 裂 化获得的水相产物的选择性随着反应的进行仍然呈现 一个缓慢增大的趋势. 这也说明催化剂表面一些涉及脱 水反应的初步转化未受到明显影响.

\subsection{3. 油相产物组成}

油相产物组成随反应时间的变化如图8所示. 在 180 $\min$ 以前, 油相产物的组成较为稳定, 芳烃含量在 $90 \%$ 左 右, 脂肪烃含量在 $9 \%$ 左右, 其余为微量的含氧副产物. 随着反应的进行, 伴随着催化剂失活加剧, 芳香烃含量 开始降低, 而脂肪烃和含氧副产物的含量则明显升高. 当反应进行到 $330 \mathrm{~min}$ 时, 芳香烃含量降至 $50.0 \%$, 同时 脂肪烃和含氧副产物的含量分别增大至 $31.6 \%$ 和 $18.4 \%$. 芳香烃含量的降低反映了催化剂芳构化能力的下降. 同 时, 更多的以醇类和酮类为主的含氧副产物的生成说明 催化剂整体脱氧效率下降, 即催化剂虽然实现了羟基丙 䣯、环戊酮和乙醇的完全转化, 但发生的很多反应是不 完全脱氧.

\subsection{4. 气体产物组成}

尾气组成随反应时间的变化如图9所示. 总的来看, 除了 $\mathrm{C}_{2} \mathrm{H}_{4}$, 其他气体产物的浓度体均呈下降趋势. 在反 应初期, 主要气体产物是 $\mathrm{C}_{3} \mathrm{H}_{8}, \mathrm{CO}$ 和 $\mathrm{CO}_{2}$, 其浓度分别约 为 $40 \%, 16 \%$ 和 $15 \%$. 随着催化剂活性下降, 到 $210 \mathrm{~min}$ 时, 
这三种气体产物的浓度分别降至 $33.6 \%, 13.9 \%$ 和 $12.3 \%$, 与此同时, $\mathrm{C}_{2} \mathrm{H}_{4}$ 浓度由初期的 $3 \%$ 左右显著增大至 $17.9 \%$. 在前面对液体产物选择性的分析中也发现, 油相产物的 选择性是在 $210 \mathrm{~min}$ 时开始明显降低的, 这进一步证明了 此时油相选择性的降低主要是由于催化剂芳构化能力 的下降, 导致中间产物 $\mathrm{C}_{2} \mathrm{H}_{4}$ 未发生芳构化形成液体芳烃 即被释放出来. 当反应进行到 $330 \mathrm{~min}$ 时, $\mathrm{C}_{3} \mathrm{H}_{8}, \mathrm{CO}$ 和 $\mathrm{CO}_{2}$ 的浓度分别降至 $1.9 \%, 2.4 \%$ 和 $2.7 \%$, 同时其他气体 产物浓度都在 $1 \%$ 以下, 而 $\mathrm{C}_{2} \mathrm{H}_{4}$ 浓度已高达 $90.79 \%$, 这说 明此时芳构化反应强度已经很弱, 与此时极低的油相产 物选择性(3.5\%)相对应.

\section{4. 催化剂再生}

前面对催化剂稳定性的研究结果表明, 催化剂活性 随着反应的进行逐渐降低. 催化剂活性的降低主要是由 于催化剂表面积炭, 覆盖了表面活性中心, 堵塞了孔道. 因此, 我们通过燃烧积炭对 $240 \mathrm{~min}$ 反应后的催化剂进行 再生, 研究再生后催化剂是否能恢复活性, 反应工况为 $400{ }^{\circ} \mathrm{C} / 2 \mathrm{MPa}$. 再生的燃烧温度为 $550{ }^{\circ} \mathrm{C}^{[18]}$, 总共再生 4 次.

\subsection{1. 反应物转化率}

反应物转化率如图10所示. 在使用新鲜HZSM-5催 化剂进行共裂化的过程中, 美基丙酮、环戊酮和乙醇保 持了接近 $100 \%$ 的转化率. 乙酸的转化率在 $240 \mathrm{~min}$ 出现 下降, 达到 $76.7 \%$. 在 $240 \mathrm{~min}$ 反应后对催化剂进行第一 次再生, 继续反应后乙酸的转化率又重新达到 $99 \%$ 以上, 而其他三种反应物的转化率仍然接近 $100 \%$. 在后续连 续实验中, 催化剂的再生也都很好恢复了催化剂对乙酸 的转化能力, 使乙酸的转化率由失活时的 $80 \%$ 左右重新 回到 $99 \%$ 以上, 同时其他反应物保持接近 $100 \%$ 的转化 率.

\subsection{2. 液体产物选择性}

液体产物选择性如图 11所示. 在第一次再生之前, 油相选择性已由初始阶段的 $31 \%$ 左右降至 $19.3 \%$. 催化 剂经再生后, 油相选择性重新达到 $30 \%$ 以上. 在后续实 验中, 催化剂再生也都使原本芳构化能力明显下降的催 化剂基本恢复了活性. 总的来看, 催化剂再生使催化剂 寿命得到了有效延长.

\subsection{3. 油相组成}

油相组成如图 12所示. 相比于初始反应阶段, 240 $\min$ 时油相中的芳烃含量由 $92 \%$ 降至 $79.1 \%$, 而脂肪烃和 含氧副产物的含量分别由 $7.6 \%$ 和 $0.3 \%$ 增大至 $15.2 \%$ 和 $5.7 \%$. 经再生后, 芳烃含量恢复到 $90 \%$ 以上, 这也说明催 化剂的芳构化能力在再生后得到了良好的恢复.

\subsection{4. 尾气组成}

在前面的连续实验中发现, 尾气中 $\mathrm{CO}, \mathrm{CO}_{2}, \mathrm{C}_{2} \mathrm{H}_{4}$ 和 $\mathrm{C}_{3} \mathrm{H}_{8}$ 浓度随着催化剂失活变化较大. 因此, 对这四种气 体在再生前后的浓度进行了监测, 结果如图13所示. 在 催化剂开始失活以后, $\mathrm{CO}$ 和 $\mathrm{CO}_{2}$ 的浓度出现下降, 而 $\mathrm{C}_{3} \mathrm{H}_{8}$ 的浓度由初始阶段的 $43 \%$ 降至 $22.6 \%$, 相应的 $\mathrm{C}_{2} \mathrm{H}_{4}$ 的浓度由 $2.6 \%$ 显著增大至 $32.6 \%$. 催化剂经过再生后, $\mathrm{C}_{2} \mathrm{H}_{4}$ 的浓度重新降至 $5 \%$ 以下, 证明催化剂的芳构化能 力得到了较好的恢复, 使得大部分中间产物 $\mathrm{C}_{2} \mathrm{H}_{4}$ 都参与 到后续的芳构化反应中.

\section{4. 结论}

本文在固定床上考察了生物油中典型模化物羟基 丙酩、环戊酮、乙酸与乙醇的共裂化特性. 研究发现, 较 高的反应温度和压力能够促进反应物的完全转化和液 体烃类的生成, 同时改善粗汽油相的组成. 考虑到较高 的反应温度会增加能耗, 较高的反应压力会增加操作的 复杂性, $400{ }^{\circ} \mathrm{C}$ 和 $2 \mathrm{MPa}$ 是较为合适的反应工况. 在 $400{ }^{\circ} \mathrm{C}$ 和 $2 \mathrm{MPa}$ 时, 生物油的酮酸混合模化物呈现良好 的裂化特性, 反应物接近完全转化, 产生高品质的汽油 相产物, 粗汽油相的选择性达到 $31.5 \%$, 且全部由烃类组 成, 其中芳香烃含量高达 $91.5 \%$, 且主要包含苯、二甲苯 等 $\mathrm{C}_{7}-\mathrm{C}_{10}$ 的小分子芳香烃. 反应后催化剂的表征结果表 明, 催化剂反应后会出现比表面积下降和表面积炭. 催 化剂稳定性测试结果表明, 催化剂会在 $330 \mathrm{~min}$ 的反应后 出现失活. 催化剂再生实验结果表明, 通过燃烧积炭的 方法对催化剂进行再生, 能够很好地恢复催化剂活性, 延长了催化剂寿命. 由于小分子酮类和酸类是生物油分 子蒸馏蒸出馏分的主要组分, 酮酸混合模化物在最佳工 况下的顺利转化也证明了生物油实际馏分与乙醇共裂 化的可行性. 